Florida International University FIU Digital Commons

11-15-1999

\title{
The rodent fauna of Long Pine Key, Everglades National Park: a comparison of habitat types
}

Carlos J. Calandriello

Florida International University

DOI: $10.25148 /$ etd.FI14052535

Follow this and additional works at: https://digitalcommons.fiu.edu/etd

Part of the Biology Commons

\section{Recommended Citation}

Calandriello, Carlos J., "The rodent fauna of Long Pine Key, Everglades National Park: a comparison of habitat types" (1999). FIU Electronic Theses and Dissertations. 1971.

https://digitalcommons.fiu.edu/etd/1971

This work is brought to you for free and open access by the University Graduate School at FIU Digital Commons. It has been accepted for inclusion in FIU Electronic Theses and Dissertations by an authorized administrator of FIU Digital Commons. For more information, please contact dcc@fiu.edu. 
FLORIDA INTERNATIONAL UNIVERSITY

Miami, Florida

THE RODENT FAUNA OF LONG PINE KEY, EVERGLADES NATIONAL

PARK: A COMPARISON OF HABITAT TYPES

\author{
A thesis submitted in partial fulfillment of the \\ requirements for the degree of \\ MASTER OF SCIENCE \\ in \\ BIOLOGY
}

by

Carlos J. Calandriello

1999 
To: Dean Arthur W. Herrioit

College of Arts and Sciences

This thesis, written by Carlos J. Calandriello, and entitled The Rodent Fauna of Long Pine Key, Everglades National Park: A Comparison of Habitat Types, having been approved in respect to style and intellectual content, is referred to you for judgement.

We have read this thesis and recommend that it be approved.

Dr. Alice Clarke

Dr. Daniel Childers

Dr. Maureen A. Donnelly, Major Professor

Date of Defense: November 15, 1999

The thesis of Carlos J. Calandriello is approved.

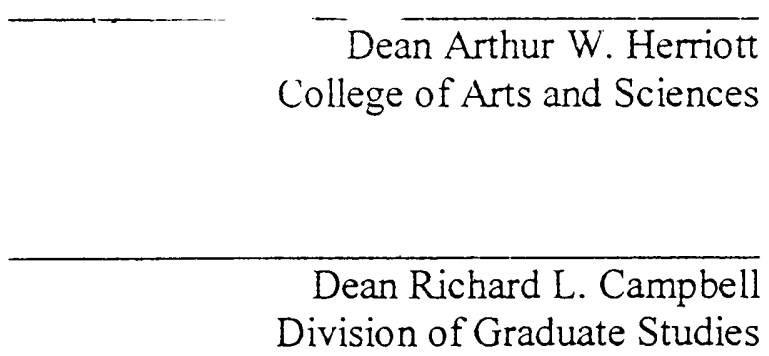

Florida International University, 1999 
(C) Copyright 1999 by Carlos J. Calandriello

All rights reserved. 


\section{DEDICATION}

I dedicate this thesis to my family and Kirsten for always being there when I needed them and close by even when I didn't. Without their help the completion of this work would not have been possible. 


\section{ACKNOWLEDGEMENTS}

This research was funded by the Florida International University Tropical Biology Program. I would also like to thank the Tropical Biology Program for awarding me a summer research fellowship, which allowed me to toil unfettered by other obligations. I would like to thank the National Park Service Air Resources Division for providing all the indispensable weather data. I want to thank my committee, Dr. Maureen A. Donnelly, Dr. Daniel Childers, and Dr. Alice Clarke for all their guidance and help throughout my graduate career. Dr. Donnelly not only proved to be a great major professor, but also a wonderful friend. My lab mates Kirsten Hines, Hardin Waddle, James Watling, Tina Ugarte, Ralph Saporito, Megan Chen, and Dennis Gorsuch provided invaluable help, irreplaceable friendship, and lots of laughs. My parents, as always helped me with everything I could have asked for, and some things I didn't. Finally, I would like to give a special acknowledgement to Dr. Steven Oberbauer and Kevin Whelan for lighting the spark in me and showing me how to be a biologist. I cannot thank them enough for all the support and inspiration they have offered me over the years. I am forever grateful and eternally indebted. 


\begin{abstract}
OF THE THESIS
THE RODENT FAUNA OF LONG PINE KEY, EVERGLADES NATIONAL PARK:

A COMPARISON OF HABITAT TYPES

by
\end{abstract}

Carlos J. Calandriello

Florida International University, 1999

Miami, Florida

Professor Maureen A. Donnelly, Major Professor

Rodents are often involved at several stages of trophic dynamics. Consequently they often play crucial roles in the structure and function of many complex ecological systems. This study sought to address the lack of baseline data concerning rodents in tropical areas, and south Florida in particular. Live trapping took place in the four major habitat types of the Long Pine Key area of Everglades National Park over the course of one year. I compared population structures and abundance of murid rodents in the four habitat types, and tested multiple weather variables for their effectiveness as predictors of rodent abundance. I found the Long Pine Key area to be depauperate in terms of species diversity. Each of the four species of rodent encountered favored a particular habitat type. The density of the understory vegetation and the avoidance of avian predators in particular appear to be the most important factors in the distribution and abundance of rodents in the Long Pine Key area of Everglades National Park. 
TABLE OF CONTENTS

CHAPTER

PAGE

I. INTRODUCTION

Background

II. METHODS 9

Study Area $\quad 9$

Climate 19

Sampling Methods $\quad 24$

Analysis $\quad 29$

$\begin{array}{ll}\text { III. RESULTS } & 34\end{array}$

Mark-Recapture $\quad 34$

Abiotic Factors 36

Vegetational Analysis $\quad 55$

Sampling Effort $\quad 55$

Estimation of Population Size $\quad 55$

IV. DISCUSSION 64

$\begin{array}{ll}\text { Mark-Recapture } & 70\end{array}$

Abiotic Factors $\quad 74$

Sampling Effort $\quad 75$

Estimation of Population Size $\quad 78$

$\begin{array}{lll}\text { V. CONCLUSION } & 79\end{array}$

$\begin{array}{lr}\text { LITERATURE CITED } & 82\end{array}$

$\begin{array}{lr}\text { APPENDIX } & 90\end{array}$ 


\section{LIST OF TABLES}

$\begin{array}{ll}\text { 1. Species list of murid rodents. } & 7\end{array}$

2. Endemic vegetation of south Florida pinelands. 14

3. Endemic vegetation of south Florida hammocks. 16

4. Endemic vegetation of south Florida wetlands. 18

5. Number of individuals captured in each location. 35

6. Correlations between weather variables and abundance. 49

7. Population estimates for Peromyscus gossypinus. 58

8. Population estimates for Sigmodon hispidus in Pineland 1. 59

9. Population estimates for Sigmodon hispidus in Pineland 2.

10. Population estimates for Peromyscus gossypinus in Hole-in-the-Donut. 61

11. Population estimates for Rattus rattus in Hole-in-the-Donut. 62 


\section{LIST OF FIGURES}

FIGURE

PAGE

1. Map of Long Pine Key, Everglades National Park.

2. Map of Everglades National Park and original extent of Miami Rockridge.

3. Mean noonday temperature and humidity per month.

4. Mean midnight temperature and humidity per month.

5. Total monthly rainfall.

6. Number of males and females captured for each species.

7. Monthly abundance of Peromyscus gossypinus.

8. Monthly abundance of Sigmodon hispidus.

9. Monthly abundance of Rattus rattus.

10. Monthly abundance of Oryzomys palustris.

11. Percent of total males and females captured per month.

12. Number of males and females of Peromyscus gossypinus captured per month.

13. Number of males and females of Sigmodon hispidus captured per month.

14. Number of males and females of Oryzomys palustris captured per month.

15. Number of males and females of Rattus rattus captured per month.

16. Scatterplot of total monthly rainfall and abundance. 
17. Scatterplot of noon temperature and abundance.

18. Scatterplot of midnight temperature and abundance.

19. Scatterplot of noon humidity and abundance.

20. Scatterplot of midnight humidity and abundance.

21. Species accumulation curve.

22. Monthly density of Peromyscus gossypinus in hammock

23. Monthly density of Sigmodon hispidus in Pineland 1.

24. Monthly density of Sigmodon hispidus in Pineland 2.

25. Monthly density of Peromyscus gossypinus in Hole-in-the-Donut.

26. Monthly density of Rattus rattus in Hole-in-the-Donut

27. Cluster diagram using population data. 


\section{Introduction}

While many studies have been conducted on the natural history and community ecology of mammals of the north-temperate zones (Mares and Ernest 1995) few studies have focused on tropical or sub-tropical rodents. Studies of northern rodents and lagomorphs (Trostel et al. 1987; Hanski et al. 1991; Korpimaki and Nordahl 1998) in particular have advanced our understanding of population dynamics and the role of trophic interactions in the stability, structure, and function of many biological communities. Fleming (1975) noted the lack of baseline data concerning the systematics, natural history, distribution, and population and community ecology of tropical mammalian species. The lack of baseline data is a curious phenomenon because rodents are useful indicators of the health and integrity of biological systems as a result of their short life spans, widespread distribution, and their tendency to be encountered in high population densities. Furthermore, due their ubiquitous distributions and high densities, rodent communities are easily accessible, and have low handling costs (Rexstad 1994).

My study was designed to describe the rodent species diversity of the four prominent habitat types found within the Long Pine Key (LPK) region of Everglades National Park (ENP), and provide a species list of murid rodents in order to address the lack of baseline data concerning small mammals in the region. I obtained the age structure and sex ratios of populations found in each vegetation type. I also conducted comparisons among the four habitat types to determine species associations with habitat characteristics. I obtained counts of species richness within each cover type using markrecapture data, and I made estimates of relative abundance using two methods. I also 
obtained population densities for all LPK rodent species in their primary habitats. In addition I incorporated climatological data (mean maximum, and minimum temperatures, mean maximum, and minimum daily relative humidity, and total monthly precipitation) to examine the relationships among climatic variables and the abundance of rodents. Also, I used the results obtained from my study to discuss the possible effects of the current prescribed burning regime on rodent populations of LPK, and other habitat management considerations.

\section{Background}

Rodents have been shown to play key roles in the structure and function of many complex ecological systems (Ostfeld et al. 1996; Elkinton et al. 1996) as a result of their role in various levels of trophic interactions as primary herbivores, insectivores, and seed predators. Rodents also serve as the main prey source for many mammalian, reptilian, and avian predators. Consequently, rodents play a crucial role in food web dynamics. Longterm monitoring of rodent populations may allow us to anticipate changes in predator populations (Hanski et al. 1993).

The Order Rodentia is the largest order of mammals, compromising 28 living families and more than 2,000 species, almost half of all known mammalian species (Wilson and Reeder 1993). This ecologically diverse group of organisms has a worldwide distribution, and is found in environments including tropical forests, desert, arctic, and alpine systems. Members of this order can be aquatic or semiaquatic, fossorial, terrestrial, or arboreal. The family Muridae is the largest and most successful family of mammals comprising more than 1,300 species. The family includes all the common rodents such as 
the rats, mice, hamsters, lemmings, gerbils, and voles (Musser and Carleton 1993). Murid rodents show a wide range of food habits and may eat plant material as well as invertebrates and small vertebrates (Cole and Wilson 1996).

The population dynamics of rodents have been shown to be affected by a wide variety of ecological variables. Resource abundance and competition, habitat fragmentation and succession, productivity, habitat structure and composition, dispersal capacities of rodents and their predators, and variations in fruiting phenologies and seasonal fluctuations in precipitation all affect rodent population size (Foster 1982; Abramsky and Rosenzweig 1984; Anderson 1989; Ims and Steen 1990; Adler 1994; Mares and Ernest 1995; Adler and Beatty 1997). Reproductive effort in rodents can vary over short periods of time. Changes in litter size, size of offspring, and age and size at time of sexual maturity may all be due to changes in resource availability and population density (Adler and Beatty 1997). Although adjustments in reproductive effort are made at the level of individuals, population level characteristics such as the proportion of individuals that are reproductively active, and the length of the breeding season are also affected by population density and resource availability (Adler and Levins 1994). Studies of frugivorous vertebrates in Neotropical dry forests have demonstrated that the fluctuations in population density may be in response to the highly seasonal environments which they inhabit (Fleming 1979). In Neotropical lowland forests, differences in rainfall have been shown to induce seasonality in overall fruit production by affecting the onset of fruiting (Foster 1982). These seasonal changes in the amount of fruit produced may impact the population of frugivorous rodents because famine conditions are produced 
when climatic conditions alter patterns of fruiting phenology. Fleming (1971)

demonstrated that annual cycles of reproductive activity in some species of Neotropical rodents, often coincides with patterns of fruit production. This pattern of fluctuations has also been observed in temperate forest rodents (Adler and Beatty 1997). In Neotropical rodents, the fluctuations in population density and reproductive activity appear to be asynchronous. This asynchrony may be due to the use of environmental cues such as seasonality in rainfall or photoperiod to trigger the start, and signal the end of the breeding season. The high diversity and patchiness of tropical forests may also contribute to the asynchronous fluctuations in population density and reproductive effort. The LPK area is similar to many Neotropical forests in that patterns of precipitation exhibit marked seasonality, and the various vegetation types show a patchy distribution throughout the area. My study provides data on the temporal variation of the rodent communities in LPK, and the relationship between the abundance of rodents and environmental variables such as precipitation, temperature, and humidity.

Many studies have attempted to identify a relationship between species diversity and plant productivity, but these studies are often contradictory to each other (Owen 1988; Rosenzweig 1992). Some studies have demonstrated a positive correlation between species diversity and productivity (Pianka 1967; Kirchner 1977; Currie and Paquin 1987), while other studies have demonstrated a negative correlation between diversity and productivity (Silvertown 1980). The lack of a suitable productivity variable in some biomes further complicates matters. Tilman (1982) suggested that plant diversityproductivity patterns should conform to hump shaped curves where species diversity is 
low at either end of the spectrum, and attains its zenith at some middle value of productivity. In their studies of desert flora, Shmida et al. (1986) observed high species diversity in moderately productive environments. Several studies concerning mammalian species diversity have also found this unimodal pattern. In a study of small mammals in sandy and rocky communities in Israel, Abramsky and Rosenzweig (1984) found that diversity of rodents declined after productivity grew beyond some threshold, thus the species diversity-productivity pattern was also characterized by a unimodal distribution. Studies of Texas carnivores (Owen 1988) found the pattern, but failed to detect the unimodal distribution in bats. Interestingly enough, Owen found that rodents diversity actually declined as productivity increases. The study by Owen (1988) and results from other studies led Rosenzweig (1992) to conclude that that the diversity-productivity pattern for rodents in the United States is unimodal. The reduced abundance of animals in southeastern Florida compared to northern Florida and other temperate areas to the north, appears to be in accordance with the assertion that pinelands and most other habitat types in south Florida are oligotrophic (Snyder 1986). The baseline data obtained in my study, concerning the species diversity and abundance of rodent communities in the oligotrophic environs of LPK will serve as useful tools in determining the nature of the relationship between habitat productivity and species diversity.

Factors other than productivity have also been proposed for the reduced species diversity and species richness found in southern Florida. Herpetological studies (Busack and Hedges 1984) have shown a reduction in the number of species as one proceeds from north to south along a latitudinal gradient down the Florida peninsula. Busack and 
Hedges (1984) proposed that the reduction in the number of species of snakes and lizards was the result of a reduction in habitat quality. Studies of herpetological communities of the LPK region of ENP (Dalrymple 1988) showed that the herpetofauna of LPK has a moderate level of diversity compared to the sandhill and scrubpine communities of Northern Florida. This finding is not contradictory to the hypothesis that upland forest regions are oligotrophic and therefore these communities would house a reduced number of species in comparison to habitats with great productivity. Amphibians and reptiles of LPK are predominantly habitat generalists, most often preferring three of the four habitat types found in the region (Dalrymple 1988). Many of the amphibian and reptile species do not rely exclusively on the pinelands. Rather, they prefer contiguous areas of pinelands that are interspersed with tropical hardwood hammocks and seasonally flooded prairies. Consequently, the presence and success of amphibians and reptiles in LPK may not be significantly affected by the low productivity of the pinelands.

In an analysis of mammalian species distributions as described by several popular field guides (Burt and Grossenheider 1980; Boitani and Bartoli 1983; Gingerich 1996; Whitaker 1997), I found that south Florida contains fewer mammal species than northern Florida, and the more temperate regions to the north (Table 1). This reduction in species diversity would seem unexpected, particularly for murid rodents, because the greatest diversity within this family is found in tropical areas (Macdonald 1995; Cole et al. 1996). Subtropical upland communities such as those found in southeastern Florida, and LPK in particular, provide habitats that are somewhat similar in terms of ecology to those of both the temperate zone and Neotropical areas (Simpson 1964). 
Table 1. Species list of Murid rodents occurring in the three geographic areas (Gingerich 1996; Whitaker 1997). South Florida is defined as all areas south of Lake Okeechobee. Species in Long Pine Key are based on data gathered during this study.

\begin{tabular}{lll}
\hline \multicolumn{1}{c}{ Florida } & South Florida & Long Pine Key \\
\hline & & \\
Peromyscus gossypinus & Peromyscus gossypinus & Peromyscus gossypinus \\
Peromyscus polionotus & Podomys floridanus & Sigmodon hispidus \\
Podomys floridanus & Sigmodon hispidus & Oryzomys palustris \\
Ochrotomys nutalli & Oryzomys palustris & Rattus rattus \\
Reithrodontomys humulis & Neofiber alleni & \\
Neotoma floridana & Mus musculus & \\
Neotoma floridana smalli & Rattus norvegicus & \\
Sigmodon hispidus & Rattus rattus & \\
Oryzomys palustris & Oryzomys argentatus & \\
Oryzomys argentatus & Neotomafloridana smalli & \\
Neofiber alleni & & \\
Microtus pinetorum & \\
Microtus pennsylvanicus & \\
Mus musculus & \\
Rattus norvegicus & \\
Rattus rattus & \\
\end{tabular}


The peninsular character of south Florida may be responsible for the low species diversity found in this area. Large peninsulas exhibit a noticeable tendency to have fewer species than otherwise similar inland regions (Simpson 1964), and as a general rule species richness decreases as a function of the distance from the northern base of the peninsula (Taylor and Regal 1978). This decrease in species richness maybe the result of greater extinction and, or lower rates of immigration along peninsulas in comparison to the mainland. It follows from island biogeography theory (MacArthur and Wilson 1967) that there will be fewer species at the southern tip of a peninsula because local extinctions are not replenished through recolonizations as easily as populations near the base of a peninsula. The absence of a "rescue effect" has lead some researchers (Taylor and Regal 1978) to conclude that lower levels of diversity encountered on other peninsulas (Baja California) are due to the geometry and geographic character of the land.

Other studies of vertebrates on peninsulas (Lawlor 1983; Barbosa and Benzal 1996) have discounted the peninsular effect as a reason for lower species richness. Lawlor (1983) found that there was little variation in the species richness of mammals from northern to southern Baja California. There was no difference between the two areas in the numbers of species of insectivores, lagomorphs, carnivores, or murid rodents. In a study of small mammals conducted on the Iberian Peninsula, Barbosa and Benzal (1996) rejected the hypothesis of a peninsular effect, and found no difference in the abundance of small mammals between northern and southern Spain, and northern Morocco. They concluded that the latitudinal pattern observed in the abundance and diversity of small mammals in the region was a result of the poor conditions of the Mediterranean 
environment for small mammals. For whatever reasons, south Florida does not follow the trend of increased species density of terrestrial mammals as one moves from north to south. Simpson (1964) found that this area was comparable to extreme northwestern Alaska, an area with a very low species density. Both areas exhibited a density measure of only 35 species per quadrat (150 miles square).

\section{Methods}

\section{Study area}

This study was conducted in the Long Pine Key region (Figure 1) of Everglades National Park, USA (Figure 2). The park is located in the southwestern corner of Florida. Long Pine Key is situated at $25^{\circ} 23^{\prime} \mathrm{N}$ latitude, and it is the largest remaining natural upland region of the original Miami Rockridge physiographic province (Davis 1943). This outcropping of oolitic limestone forms the southern end of the Atlantic coastal ridge, which comprises the eastern boundary of the Everglades basin. The original Miami Rockridge was previously dominated by pine rockland forests, and extended from Miami in a southwestwardly direction into the city of Homestead and further west into Everglades National Park (Snyder 1986). The maximum elevation of the outcropping in the park is less than $2 \mathrm{~m}$. As part of Everglades National Park, LPK has been protected from most human interference for over forty years. The LPK region occupies approximately 8,000 hectares and is composed of four major vegetation types, pinelands, tropical hardwood hammocks, wet prairies, and a disturbed area known as the Hole-inthe-Donut, composed of a monoculture of Brazilian Pepper (Schinus terebinthifolius). 


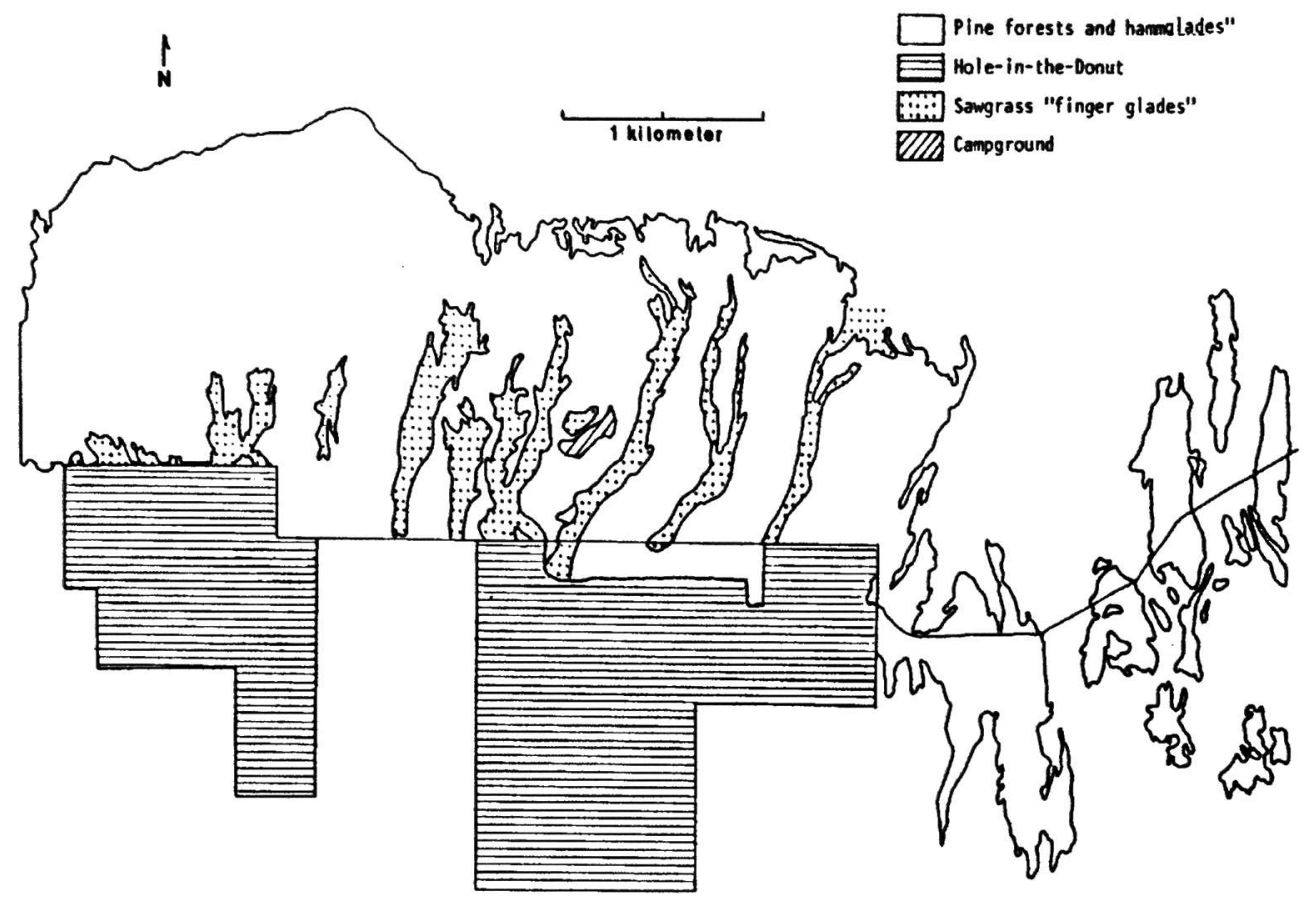

Figure 1. Map of Long Pine Key, Everglades National Park. (Loope and Dunevitz 1981). 


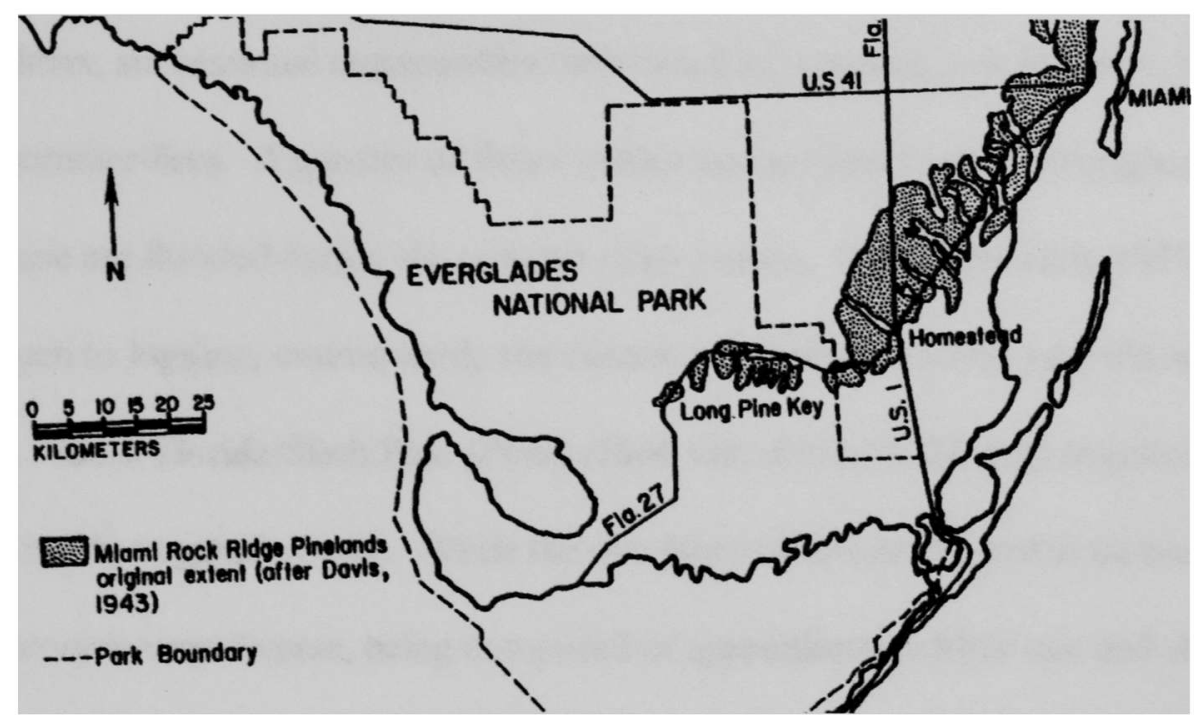

Figure 2. Map of Everglades National Park boundary and original extent of Miami Rock Ridge Pinelands. (Snyder 1986). 
The pinelands cover about 4,650 hectares in LPK (Dalrymple 1988). They are sub-climax, successional communities maintained by frequent, low intensity, late spring or early summer fires. A number of finger glades and are interspersed throughout the area, and these are flooded during the summer rainy season. During the early 1930s the area was open to logging, consequently the current pinelands are 30-40 year old second growth forest. South Florida Slash Pine (Pinus ellioti var. densa) is the only overstory species found in this vegetation type. While the overstory of this cover type is monospecific, the understory is very diverse, being composed of approximately forty tree and shrub hardwood species. Most of the hardwoods are tree species that are maintained as shrubs by frequent fires. These hardwoods include Ardisia escallonioides, Metopium toxiferum, Bumelia salicifolia, Guettarda scabra, Metopium toxiferum, and Myrsine floridana (Snyder 1986).

Approximately half of all plant taxa found in the pinelands have West Indian distributions, including most of the hardwood species (Loope and Dunevitz 1981; Snyder 1986). In his studies of the effects of fire on the vegetation of Everglades National Park, and the breeding birds of the area, Robertson $(1953,1955)$ detailed the presence of a large number of endemic taxa in the flora of these pine forests. He also noted the striking similarities between south Florida pine forests and those found on the larger islands of the Bahamas archipelago. There is a great diversity of plant species in the herbaceous layer of vegetation with more than 120 herbaceous species of plants found in the pine forests (Loope et al. 1979). The herbaceous understory is dominated by grass species, but also contains forbs, sedges, and three species of ferns (Snyder 1986). Pinelands are variable in 
the number of herbaceous species that are encountered, but pinelands which are subjected to frequent burns tend to have a more developed herbaceous layer than those which burn infrequently. Many other tree, shrub and herbaceous species can be found in the pinerockland habitat (Table 2).

Pinelands of south Florida are characterized by having very little soil. The soil that exists is found in solution holes, and other crevices and depressions in the oolitic limestone substrate. In the pinelands I studied, like many of the pinelands in the area, there is very little soil exposed on the rock surface. Pineland plants receive many of their nutrients from decomposing organic matter found in cracks, depressions, and crevices in the limestone. The soil in the pinelands tends to be well drained due to the fact that the rock ridge is the highest portion of the region, and the limestone substrate is porous. The oligotrophic nature of south Florida pinelands is partly a result of the nitrogen, phosphorus, and potassium deficient soils (Snyder 1986). The nutrient poor pineland soils tend to be neutral or slightly basic due to high concentrations of calcium carbonate (Snyder 1986).

North American tropical hardwood forests are systems unique to southern Florida (Loope and Urban 1980), containing a number of plant species that do not occur in any other portion of the country. Tropical hardwood hammocks are the climax communities of the upland forest systems of ENP. Loope and Urban (1980) considered these tropical hardwood forests to be of significant esthetic and scientific value. One hundred-twenty tropical hardwood hammocks are found interspersed throughout the LPK pine-rockland matrix (Olmsted et al. 1983). Long Pine Key hammocks range in size from 0.1 hectares to 
Table 2. Endemic tree, shrub, herb, vine and fern species common to pine rocklands of south Florida (Snyder 1986; Lodge 1996). Families are according to Mabberly (1989).

\begin{tabular}{lll}
\hline Common Name & Scientific Name & Family \\
\hline \hline & & \\
Dade County Slash Pine & Pinus elliottii & Pinaceae \\
Rough Leaf Velvetseed & Guettarda scabra & Rubiaceae \\
Smooth Leaf Velvetseed & Guettarda elliptica & Rubiaceae \\
Myrsine & Myrsine floridana & Myrsinaceae \\
Marlberry & Ardisia escallionoides & Myrsinaceae \\
Saw Palmetto & Serenoa repens & Arecaceae \\
Varnish-leaf & Dodonia viscosa & Sapindaceae \\
Sweet Acacia & Acacia pinetorum & Fabaceae \\
Satin-leaf & Chrysophyllum oliviforme & Sapotaceae \\
Tetrazygia & Tetrazygia bicolor & Melastomataceae \\
Poisonwood & Metopium toxiferum & Anacardiaceae \\
Coontie & Zamia pumilia & Cycadaceae \\
Indigo Berry & Randia aculeata & Rubiaceae \\
Mouse's Pineapple & Morinda royoc & Rubiaceae \\
Locust Berry & Byrsonima lucida & Malpighiaceae \\
Partridge Pea & Cassia deeringiana & Fabaceae \\
Jacquemontia & Jacquemontia curtisii & Convulvulaceae \\
Piriqueta & Piriqueta caroliniana & Turneraceae \\
Painted Leaf & Poinsettia heterophylla & Euphorbiaceae \\
Butterfly Weed & Asclepias tuberosa & Asclepiadaceae \\
Yellowtops & Flaveria floridana & Compositae \\
Corkystem Passionflower & Passiflora suberosa & Passifloraceae \\
Bamboo Vine & Smilax laruifolia & Liliaceae \\
Rubber Vine & Echites umbellata & Apocynaceae \\
Love Vine & Cassytha filiformis & Lauraceae \\
Pine Fern & Anemia adiantifolia & Schizaeaceae \\
Bracken Fern & Pteridium aquilinum & Pteridaceae \\
& & \\
\hline \hline & & \\
& & \\
& &
\end{tabular}


91 hectares (Olmsted et al. 1980). The hammocks are at a slightly higher elevation, and have a greater soil depth than the pinelands.

Hammocks have a closed canopy composed of a mixture of tropical hardwoods (broadleaf trees) which range in height from 6-10 $\mathrm{m}$ with emergent trees reaching heights over $15 \mathrm{~m}$. Quercus virginiana is the only dominant canopy species with a temperate zone distribution. Large hardwoods such as, Bursera simaruba, Bumelia salicifolia, and Lysiloma bahamensis dominate the canopy of my study site. Smaller trees and shrubs such as, Metopium toxiferum, Psychotria nervosa, Ardisia escallionoides, Eugenia axillaris and Nectandra coriacea are found in the open and sparsely vegetated understory. A wealth of other plant species can be found throughout the study location (Table 3).

The closed canopy of the hammocks produces a microclimate that differs from that found in pine rockland forests and inundated prairies. The interior of the hammocks have increased humidity, cooler temperatures as a result of lower solar radiation, and higher soil moisture than pine rockland forests (Loope and Dunevitz 1981). The hammock microclimate, and the lack of ground level fuel sources, ameliorates the effects of fire on hardwood hammocks, in contrast to the pinelands. Most of the hammocks in LPK are completely surrounded by pinelands, and are kept small due to the prescribed burning regime of the area, and fires caused by lightning. Invasion by exotic species, such as Schinus terebinthifolius and (Casuarina spp). is considered to be one of the major threats to the health and stability of tropical hardwood hammock systems (Loope and Urban 1980). 
Table 3. Tree and shrub species commonly found in tropical hardwood hammocks of Everglades National Park (Lodge 1996). Many of the pioneering hardwoods of the pine rocklands are found as larger trees in the hammocks. Family names are according to Mabberly (1989).

\begin{tabular}{lll}
\hline \hline Common Name & Scientific Name & Family \\
\hline & & \\
Live Oak & Quercus virginiana & Fagaceae \\
Gumbo Limbo & Bursera simaruba & Burseraceae \\
Mahogany & Swietenia mahogani & Meliaceae \\
Wild Tamarind & Lysiloma bahamensis & Fabaceae \\
Mastic & Mastichodendron foetidissimum & Sapotaceae \\
Strangler Fig & Ficus aurea & Moraceae \\
Short-leaf Fig & Ficus citrifolia & Moraceae \\
Florida Royal Palm & Roystonea elata & Palmaceae \\
Lancewood & Nectandra coriacea & Lauraceae \\
Paradise Tree & Simarouba Glauca & Simaroubaceae \\
White Stopper & Eugenia axillaris & Myrtaceae \\
Pigeon Plum & Coccoloba diversifolia & Polygonaceae \\
Wild Coffee & Psychotria nervosa & Rubiaceae \\
Myrsine & Myrsine floridana & Myrsinaceae \\
Marlberry & Ardisia escallionoides & Myrsinaceae \\
Poisonwood & Metopium toxiferum & Anacardiaceae \\
Cabbage Palm & Sabal palmetto & Arecaceae \\
Hackberry & Celtis laevigata & Ulmaceae \\
Inkwood & Exothea paniculata & Sapindaceae \\
& & \\
\hline \hline
\end{tabular}


The seasonally inundated prairies of LPK occupy an area of approximately 800 hectares. These prairies are dominated by sawgrass (Cladium jamaicense), Muhlenbergia filipes, Schizachyrium rhizomatum, and a variety of herbaceous species are interspersed throughout the sawgrass (Table 4). Those prairies with an inundation period $>6$ months tend to be dominated by $C$. jamaicense that occurs in nearly monospecific stands (Lodge 1994). The soil type is marl, a biorganic periphyton composed of filamentous algae, diatoms, cyanobacteria, and green algae. The algal components of the periphyton absorb calcium carbonate into its cell wall and produces marl soil in areas where the hydroperiod lasts between 6 and 12 months. Finger glades, small short hydroperiod prairies that surround many of the pine forests of LPK, are often included as part of the prescribed burning regime in an effort to control fuel load on the ground.

The southern border of LPK is comprised of 3,600 hectares of abandoned farmland (Dalrymple 1988). Approximately $40 \%$ of this area of land known as the "Holein-the-Donut," is a monospecific stand of the exotic, invasive species Schinus terebinthifolius (Doren et al. 1997), known locally as Brazilian Pepper or Florida Holly. This introduced species was brought from Brazil as an ornamental in 1898, but did not become widely established until 40 or 50 years later. Loope and Dunevitz (1981) report that as early as 1961 Craighead noted the presence of Schinus in several localities within Everglades National Park and suggested that it could pose a threat to the native forest systems of the park. Schinus is presently considered the biggest threat to the long-term health, integrity, and biodiversity of the Everglades ecosystem (Doren et al. 1997). In the 
Table 4. Plant species commonly occurring in short hydro- period freshwater marshes, and sawgrass prairies of Everglades National Park (Lodge 1996). Family names are according to Mabberly (1989).

\begin{tabular}{lll}
\hline Common Name & Scientific Name & Family \\
\hline & & \\
Sawgrass & Cladium jamaicense & Cyperaceae \\
Swamp Lily & Crinum americanum & Liliaceae \\
Spike Rush & Eleocharis cellulosa & Cyperaceae \\
Bladderwort & Utricularia foliosa & Lentbulariaceae \\
Glades Lobelia & Lobelia glandulosa & Campanulaceae \\
Pickerel weed & Pontederia cordata & Pontederiaceae \\
Arrowhead & Sagittaria lancifolia & Alismaceae \\
Duck Potato & Sagittaria falcata & Alismaceae \\
Maidencane & Panicum hemitomon & Gramineae \\
Hairgrass & Muhlebergia capillaris & Poaceae \\
Colicroot & Aletris farinosa & Liliaceae \\
Primrose-willow & Ludwigia peruviana & Onagraceae \\
Alligator Flag & Thalia geniculata & Marantaceae \\
& & \\
\hline \hline
\end{tabular}


past the park has tried a number of methods to eradicate Schinus and restore the area.

The methods used included soil compacting, pine and hardwood plantings, graminoid and slough re-establishment, and various other attempts to control this pest species (Doren et al. 1997).

The introduction of the exotic species by the transplantation of ornamentals and agricultural plants, coupled with the island character of south Florida have helped to establish, and promote the success of exotic species, particularly Schinus terebinthifolius in Everglades National Park. Recent estimates show that almost one quarter of the total flora of the park are introduced exotic species (Whiteaker and Doren 1990). These estimates make the Everglades one of the top four national parks in the country in terms of the degree of exotic plant invasion and, threat to the biodiversity of the native flora (Loope 1992).

Aside from the four major vegetation types mentioned, LPK also has been dredged to build roads, camp sites for tourists, a Boy Scout Camp, a research center, and other structures.

\section{Climate}

A distinctive feature of south Florida is its climate. Southern Florida exhibits a moderate variation in temperature with largely frost-free winters. During the period of July 1998 through June of 1999 the mean daily high temperature during July and August hovered slightly over $30^{\circ} \mathrm{C}$, with the mean daily humidity also peaking during the summer months (Figure 3). The mean nightly low temperature during the summer months was $25^{\circ} \mathrm{C}$, with February and March registering the coolest nightly temperature. Nightly 


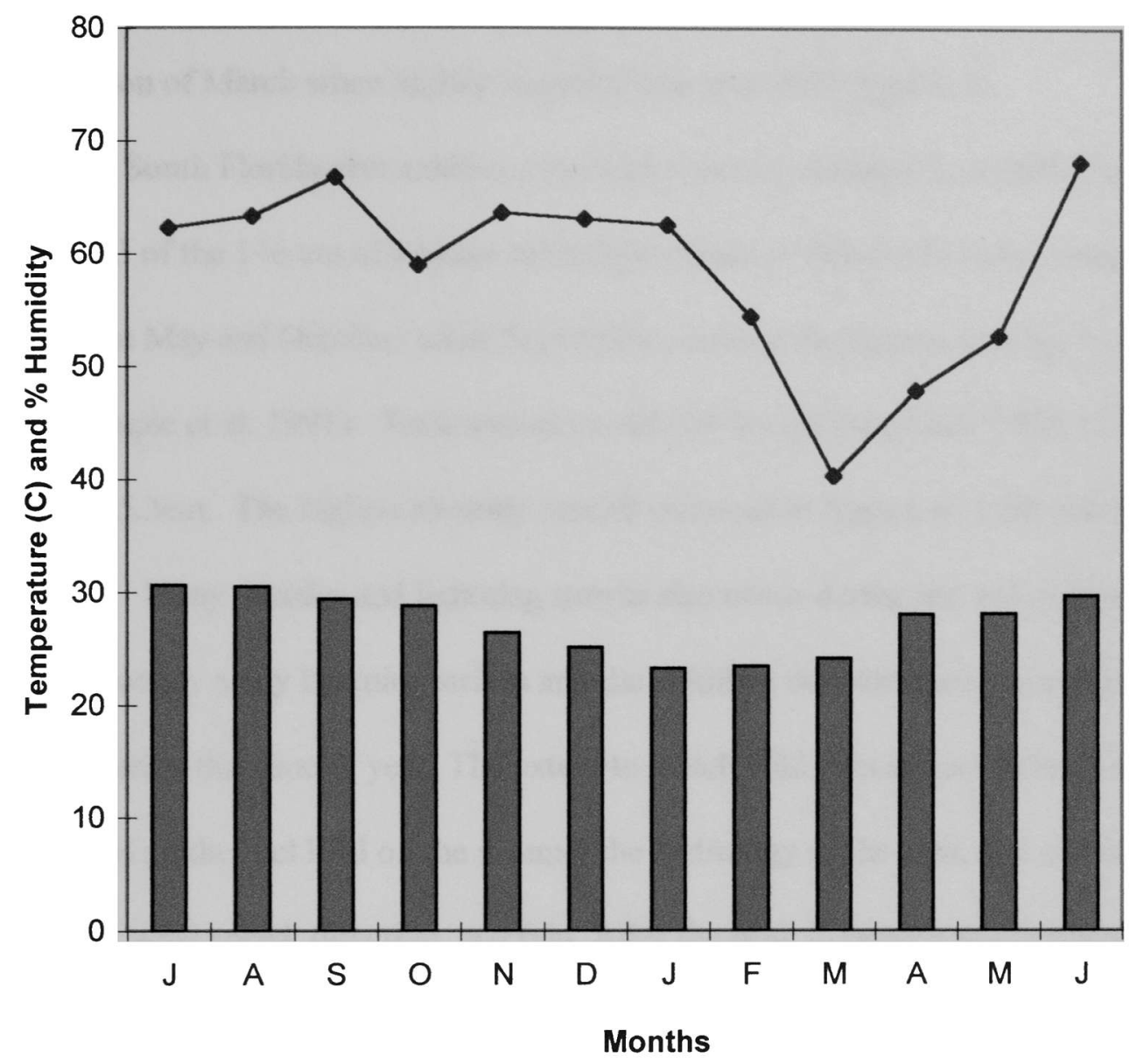

Figure 3. Mean noon day temperature and humidity per month for period July 1998-June 1999 (courtesy of National Park Service Air Resources Division). Bars represent mean noon temperature; Line represents mean noon humidity. 
humidity showed little variation throughout the year ranging near $90 \%$, with the exception of March when nightly humidity was near 70\% (Figure 4).

South Florida also exhibits a marked seasonal variation in rainfall (Figure 5). More than $2 / 3$ of the $146 \mathrm{~cm}$ of average annual precipitation falls in the hotter summer months between May and October, while September receives the highest average monthly rainfall (Dalrymple et al. 1991). Total annual rainfall for the period of July 1998, to June 1999 was $145.3 \mathrm{~cm}$. The highest monthly rainfall occurred in August of $1998(26.35 \mathrm{~cm})$.

Many thunder and lightning storms also occur during the wet summer months, consequently many lightning strikes and the wildfires that sometimes accompany them also peak during this time of year. The extent to which wild fires spread through an area depends on the fuel load on the ground, the hydrology of the area, and climatic factors such as wind speed, direction, and rain. After the peak in rainfall and lightning storms that occurs from May through October, the months of November through April are noticeably cooler and drier. November also marks the end of the hurricane season for south Florida.

Under the Koeppen system of world climate classification, south Florida is considered to have a climate akin to tropical savannas of the wet-and-dry tropics (Snyder 1986) even though geographically, southern Florida lies north of the Tropic of Cancer, widely considered the northernmost boundary of the tropics. According to Snyder (1986), the occasional occurrence of frost in south Florida suggests that the area is more appropriately classified as sub-tropical in nature. This agrees with the widely recognized Holdridge (1967) classification scheme based on temperature and precipitation which designates southern Florida as a Subtropical Moist Forest life zone. 


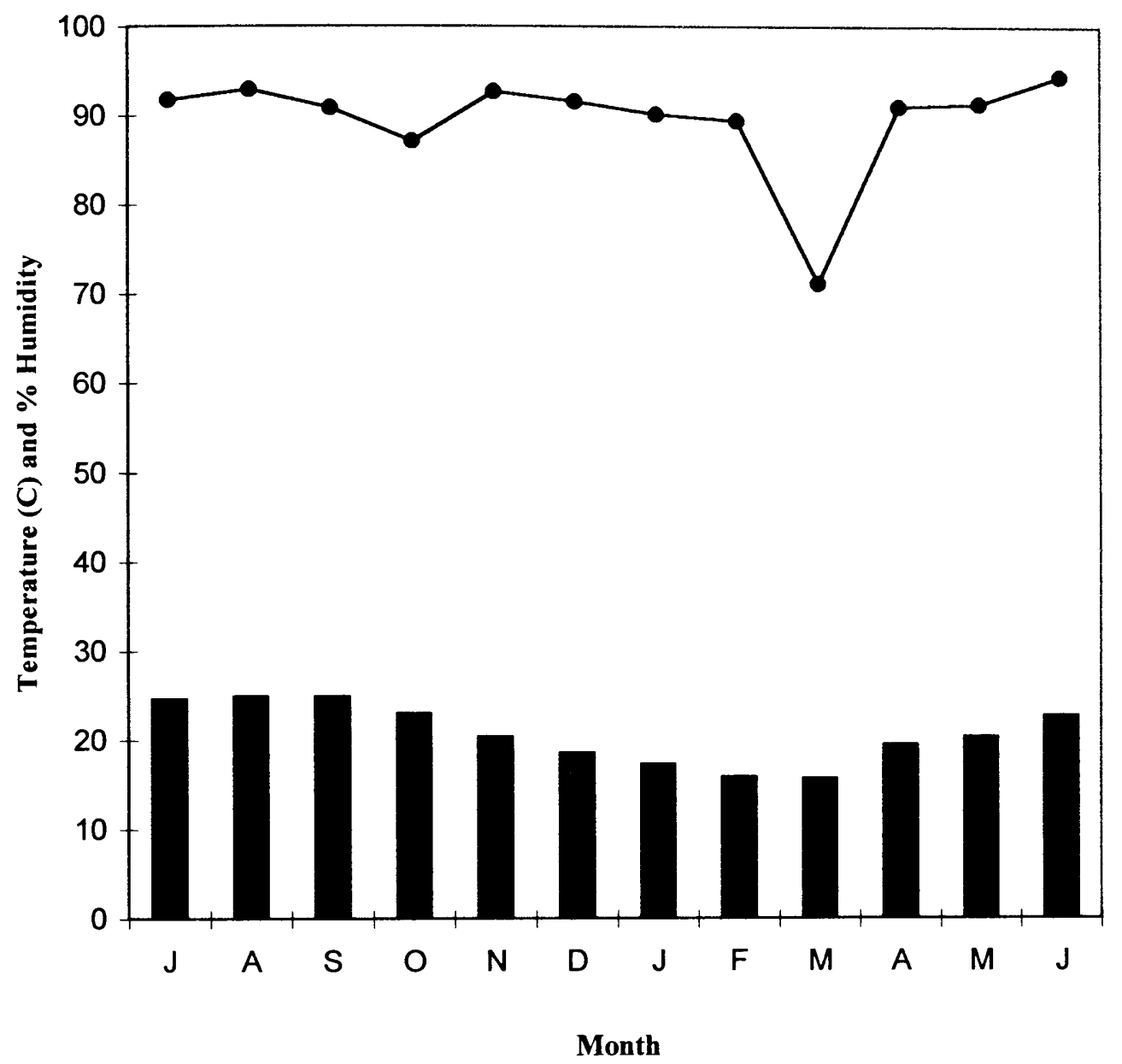

Figure 4. Mean midnight temperature and humidity per month for period July 1998-June 1999 (courtesy of National Park Service Air Resources Division). Bars represent mean midnight temperature; Dark line represents mean midnight humidity. 


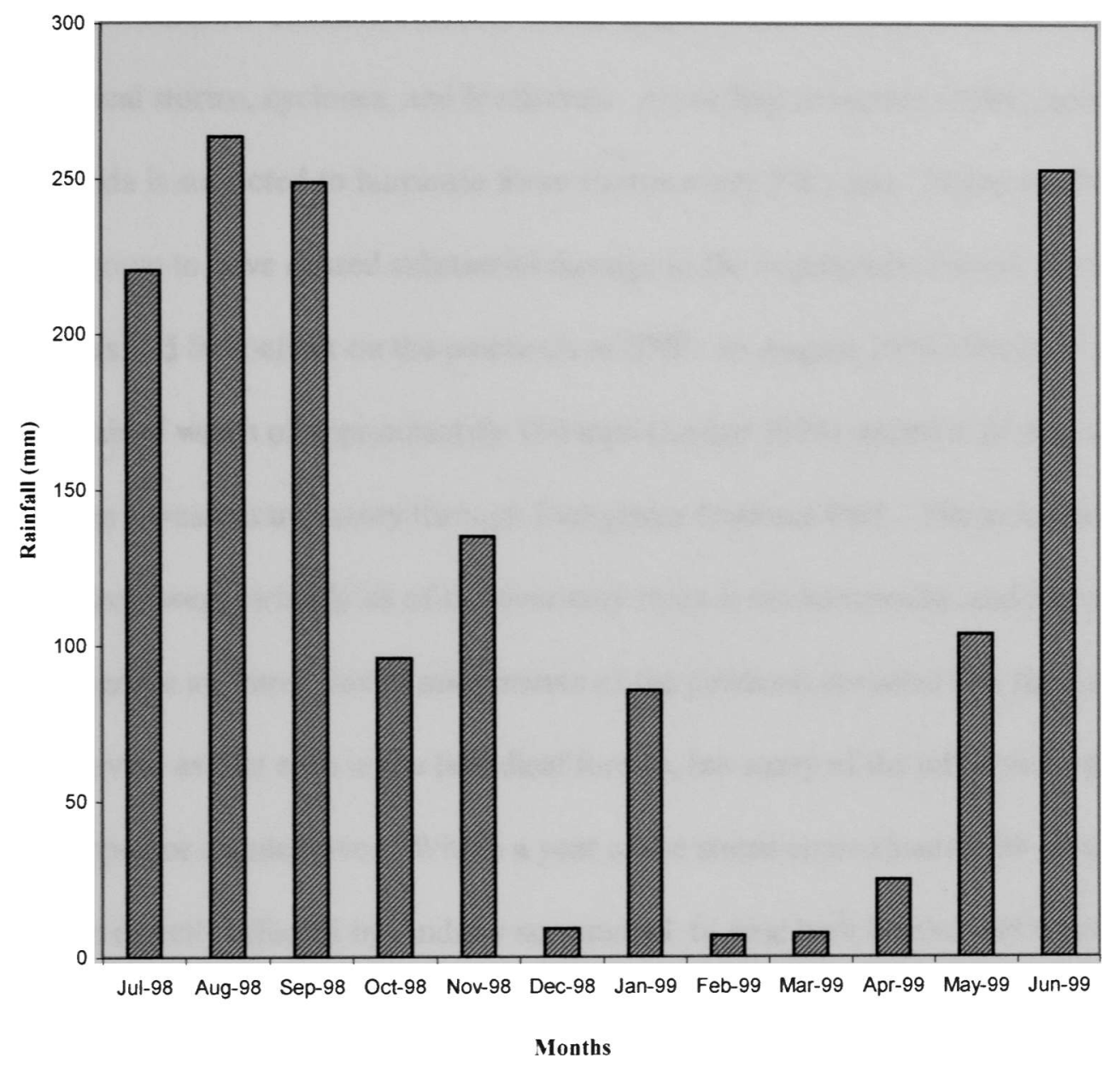

Figure 5. Total monthly rainfall for period July 1998-June 1999(mm) (courtesy NPS Air Resources Division). 
Another distinctive feature of the south Florida climate is the occurrence of tropical storms, cyclones, and hurricanes. According to Gentry (1984), southeastern Florida is subjected to hurricane force storms every 7-8 years. Hurricane Donna in 1960 is known to have caused substantial damage to the vegetation of south Florida, but the winds had little effect on the pinelands of ENP. In August 1992 Hurricane Andrew with sustained winds of approximately $150 \mathrm{mph}$ (Lodge 1994) ripped a 30 mile wide swath along a western trajectory through Everglades National Park. The areas most affected by Andrew were virtually all of the overstory trees in the hammocks, and many of the mangrove swamps. Initial assessments of the pinelands revealed that the damage was not as severe as that seen in the broadleaf forests, but many of the taller pine trees were snapped or toppled over. Within a year of the storm approximately 90 percent of the pine trees directly affected by Andrew succumbed to pine bark beetles and weevils and died (Lodge 1994). The least affected areas of the park were the sawgrass prairies and the freshwater marshes common to the area (Lodge 1994).

\section{Sampling Methods}

This study took place from July 1998 through August of 1999. Sampling occurred every month with the exception of September 1998, when ENP was closed as a result of Hurricane Georges. July was used as a prebaiting period so that the animals would become accustomed to seeing the traps and become acquainted with the bait. A total of six trapping locations within the LPK habitat mosaic were established during the course of the study. The six trapping areas included two pinelands (Redd Pineland and Grimeshaw 
Pineland), one tropical hardwood hammock (Redd Hammock), two wet prairies, and a site in the Brazilian Pepper monoculture.

I used both ventilated and non-ventilated Sherman live traps $(7.6 \times 9.5 \times 30.5 \mathrm{~cm})$ during the course of the study. Due to the large difference in the area occupied by each habitat type, I placed trapping stations in proportion to the number of hectares occupied by each habitat type sampled, according to the method of proportional allocation as explained in Conroy and Nichols (1996). The only modification to this method was that I placed no fewer than 20 traps in any habitat type, in order to assure maximum trapping success. I marked trap locations along transects using colored flagging so that trap station locations were permanent. I baited the traps with crimped oats, although gerbil food was also used during the pre-baiting period in July 1998. Trapping occurred for a period of three consecutive nights, on a monthly basis. I conducted all trapping during the period of the new moon or as close to this phase as possible because moonlight affects microhabitat use by some rodents (Bowers and Flanagan 1988).

I checked the traps early each morning on the three days of trapping. Captured individuals were transferred to a transparent specimen bag and fitted with an individually numbered ear tag using specially designed pliers, identified to species, sexed, weighed, assessed for reproductive condition, and released at the capture location. Habitat type, transect, and trap number were recorded for each individual captured. I also noted observations regarding climatic conditions or vegetation and habitat characteristics, along with miscellaneous information concerning individual rodents. I also recorded the type of trap (ventilated or non-ventilated) the animal was captured in. 
I established three, parallel $100 \mathrm{~m}$ transects in each pineland location. Transects were spaced between 20-30 m apart from each other. I began trapping in Redd Pineland in August of 1998. During this time I placed 17 traps on each transect were equidistant from each other for a total of 51 traps. I placed two traps at every other trapping station starting at the zero marker and extending to the $100 \mathrm{~m}$ marker in order to attain the requisite 17 traps per transect. In February of 1999 I added another pineland site (Grimeshaw) in order to obtain a more complete picture of the rodent communities of the pine rocklands of LPK. In keeping with the method of proportional allocation, the total number of traps in Redd pineland was reduced to 36, with the same number occurring in Grimeshaw pineland for a total of 72 traps. With the addition of the second pineland and the modification to the total number of traps in each habitat type, each of the three transects in the two pinelands contained 12 traps. Trapping stations began at the $0 \mathrm{~m}$ marker, and an additional trap was placed at the $100 \mathrm{~m}$ marker in order to achieve 12 traps.

I began trapping in the tropical hardwood hammock site in August of 1998, and continued through August of 1999. During the period of August 1998 to February 1999 the Redd Hammock (Hammock 1) site contained 3 transects $(2100 \mathrm{~m}$, and one $50 \mathrm{~m})$ with a total of 22 traps. After the addition of the second pineland site in February of 1999, I increased the number of traps in Redd Hammock to 29 in order to maintain a proportional sampling effort. I also established an experimental transect within a young hammock/mature pineland ecotone (Hammock 2) in May of 1999. Due to the small size of the transition zone, the transect was only $50 \mathrm{~m}$ in length. I established five trapping 
stations with two traps at each station every ten meters for a total of 10 traps. Sampling occurred only in the months of May 1999 and June of 1999.

I began the trapping regime in the wet prairies/marsh lands in November, 1998 (the beginning of the dry season). By this time, the water level in these habitats had dropped considerably, allowing me to establish permanent, marked transects in the area. The first wetland (Wetland 1) I chose was a short hydroperiod finger glade neighboring the Redd hammock, and Redd pineland sites. I established three parallel $100 \mathrm{~m}$ transects, and spaced them 30 meters apart from one another. Traps were placed equidistant along each transect for a total of 21 trapping stations. I marked trapping station locations using one meter high wire markers placed into the ground with multiple strips of colored flagging attached to the free end of the marker.

In February of 1999, I added a second wetland (Wetland 2) to increase sample size and gain a more accurate representation of the rodent communities of the marshes. Wetland 2 is a longer hydroperiod marsh with noticeably different vegetation from Wetland 1. While Wetland 2 was a seasonally inundated prairie with a longer hydroperiod than the finger glade site (Wetland 1), it differed in vegetational composition and hydroperiod from the true sawgrass prairies of the Taylor Slough area. I set up two 100 $\mathrm{m}$ transec in Wetland 2 with a total of 15 traps in each. After the addition of the second wetland, I modified the number of trapping stations in Wetland 1 to 15 , for a total of 30 traps in the wetland habitat type to maintain proportional trapping effort throughout the study. I continued trapping in both wetland sites through July of 1999. 
I began sampling in the Hole-in-the-Donut area in August of 1998 with a prior baiting period in the month of July 1998 . I set up only two $100 \mathrm{~m}$ permanent transects in the Schinus terebinthifolius monoculture due to the extreme difficulty of moving through the vegetation. Schinus grows as a thick, tangled mass of woody stems and branches often becoming impenetrable without the use of chainsaws and heavy equipment. I established the two transects parallel to each other and spaced 20 meters apart with ten equidistant traps on each one. After the addition of other sites, and the modifications to the number of trapping stations present in the hammock and pineland sites, I increased the number of traps in the Brazilian Pepper to 24.

In order to correct for the modifications that I necessarily incorporated to the trapping arrays and to the number of traps and transects within each of the four habitat types, I standardized measures of rodent abundance to reflect the number of captures per trap night (unit effort), rather than merely using the number of captures. In this fashion I could detect changes in rodent population size without merely attributing it to an increase the number of traps present in an area.

In November of 1998, I conducted the first of two rough estimates of percent cover, along with a characterization of the vertical component of the pine rockland vegetation, in Redd Pineland (Pineland 1). I performed the vegetational analysis so that I could use it as a direct measure of habitat quality, and examine the role of vegetation density in rodent-habitat associations.

I randomly selected ten points using a random number table to indicate the direction and distance to be walked from a previously chosen point in the center of the 
trapping area. The only stipulation was that points could not be located on trails that had been created by the establishment of the permanent transects or points where a trapping station was present. At each of the ten points I outlined a $2 \times 2 \mathrm{~m}$ square with colored flagging. I conducted a rough estimation of percent cover within the square according to one of the following previously established categories, (1) $0-30 \%$, (2) $31-40 \%$, (3) 41 $60 \%$, (4) $61-80 \%,(5)>80 \%$. The maximum height of the woody, non-pine vegetation was also noted. An overall assessment of the percent cover of the pineland was also conducted after the 10 points were sampled. The second vegetational analysis took place in March of 1999, and also included Grimeshaw Pineland (Pineland 2). A second analysis was to be conducted in only Grimeshaw Pineland during the month of July, but I omitted it after the pineland was subjected to a park administered prescription burn.

I conducted a similar analysis of percent cover in the two wetland sites in February of 1999.

I obtained weather data (precipitation, ambient temperature, and relative humidity) from the National Park Service Air Resources Division. Data were only available for the period beginning July of 1998 and ending in June of 1999. Climate data for the sampling months of July and August 1999 still have not been approved for inspection by the National Park Service.

\section{Analysis}

Variation in observability complicates comparisons of count statistics relating to species diversity (species richness and evenness) (Wilson et al. 1996). Taking this naturally occurring variability into consideration, all the methods used in this study have 
been standardized in order to both identify and control the important sources of variation in observability. I obtained count statistics using the same proportion and type of traps arranged in the same spatial configuration, and set for the same amount of time, with the same baits in all habitat types.

Due to the nature of the established sampling regimen, the time elapsed between sampling periods was very short, consequently the number of captures in each sampling period was correlated to the number of captures of previous sampling periods. Since the critical assumption of independence could not be met for traditional one way, or factorial analysis of variance (ANOVA), I used the statistical software package (STATISTICA 1997) to perform a repeated measures ANOVA to examine differences in the relative abundance of rodents occurring across multiple sampling periods, within each habitat type or study site, because the same sites were sampled every month. This analytic method constitutes a within-subjects effects analysis. I used a hierarchical tree cluster analysis (STATISTICA 1997) to examine differences and similarities among the study locations.

In order to obtain estimates of population parameters such as population size at time of sampling $\left(N_{t}\right)$, and the associated probabilities of survival $\left(\Phi_{t}\right)$, I used the JollySeber method of abundance estimation. Due to the length of the mark-recapture period of the study it was biologically unrealistic to assume that the rodent population of LPK would not constantly be changing in size as a result of births, deaths, immigration, and emigration. Consequently it was deemed necessary to use an open population estimator such as the Jolly-Seber method. To this end, I constructed Method B tables (Leslie and Chitty 1951) according to the methodologies outlined in Krebs (1999); Sutherland (1996), 
using the terminology and variables first proposed by Jolly (1965). I constructed Method B tables for each species, in each habitat type, provided that at least ten individuals of that species were captured in a particular study site (Appendix 2). I included this caveat to allow for the completion of certain mathematical calculations that would otherwise be rendered impossible, or insignificant when values of $N$ are less than ten. The variables used in the calculation of the Method B tables were as follows:

$m_{t}=$ Number of marked animals caught in sample $t$

$u_{t}=$ Number of unmarked animals caught in sample $t$

$n_{t}=$ Total number of animals caught in sample $t\left(=m_{t}+u_{t}\right)$

$s_{t}=$ Total number of animals released after sample $t$ (animals caught - accidental deaths of removals)

$m_{r t}=$ Number of marked animals caught in sample $t$ last caught in sample $r$ Using the aforementioned variables, two more variables of interest were calculated, $R_{t}$ and $Z_{t}$. The number of $s_{t}$ individuals released at sample time $t$ and caught again in some later sample is defined as $R_{t}$, while $Z_{t}$ was defined as the number of individuals that were marked before sample $t$, not caught in sample $t$, but caught in a sample after $t$ (Krebs 1999). Using the variables defined in the Method B tables, I calculated tables of population estimates such as the proportion of marked individuals $(\alpha)$, the size of the marked population $\left(M_{t}\right)$, the population size estimate $(N)$, and the probability of survival (Ф) for each time period.

I also included calculations of minimum number alive (MNA) in the tables of population estimates as a standard of comparison for the population size estimate obtained 
through the Jolly-Seber method. The minimum number alive at a given sample period is a method of direct enumeration which allows for a conservative measure of the true population size, and not an estimate of population size like the Jolly-Seber model. Enumeration methods have been widely used in small mammal studies (Krebs 1966; Smith and Vrieze 1979), and for amphibians (Donnelly 1989). While direct enumeration methods allow researchers to circumvent the assumptions associated with population estimation models such as equal catchability, all enumeration methods underestimate (negative bias) true population sizes (Krebs 1999), particularly in instances where capture probabilities are low. Krebs (1999) suggests that enumeration methods only be used when it is impractical to use population estimators such as Jolly-Seber (sample sizes less than 10 individuals per trapping period), or to be used concurrently with such models. The latter approach was adopted for this study.

The minimum number alive of a particular species during any given month also allowed me to obtain conservative measures of density for the most abundant species in each habitat type. I did not obtain a density measure for Oryzomys palustris because in almost all cases the result would have been less than one individual per unit of area. To calculate density I used the Boundary Strip method devised by Bondrup-Nielsen (1983), as outlined in Krebs (1999). Simple trapping grids and transects are often ineffective methods of obtaining density measures for a particular area because it is often difficult to know the size of the effective trapping area (Jones et al. 1996). The Bondrup-Nielsen boundary strip method uses home range size to estimate the effective size of the sampling area. I estimated the home range size of $P$. gossypinus was estimated to be 0.35 ha, 
similar to that of Mus musculus (Krebs 1999), a mouse of comparable size and body

weight. Estimates of home range size for the other three species were assumed to be 1 ha, based on their size and weight in comparison to Mus musculus.

I used body weight to determine age categories for all species captured.

Individuals of $P$. gossypinus found to have attained $20 \mathrm{~g}$ were considered adults (Layne 1974), as were individuals of Sigmodon hispidus (Dunaway and Kaye 1964) and Rattus rattus that had attained a body weight of $100 \mathrm{~g}$. Individuals of Oryzomys palustris were considered adults if they weighed $55 \mathrm{~g}$ or more (Negus et al 1961). Individuals that were found to weigh less than the predetermined weights, were classified as juveniles.

The population size of a species in a given area is determined by the effect of gains such as immigration and recruitment, and losses such as emigration and mortality. When conducting an analysis of the minimum number alive a researcher can assume that if the study is short relative to the life span of adults, then losses can be assumed to be primarily a result of emigration. Conversely if the trapping period is long relative to the life span of adults then losses are assumed to be caused by mortality. In my study the length of the trapping regime was longer than the life span of the adult rodents captured (< one year), consequently losses were assumed to be a result of mortality.

Climatological data are important factors to consider when interpreting results in mammalian studies, particularly those focused on small mammals because seasonal cycles and characteristic oscillations and fluctuations are often dependent on climate (Crump 1996). Temperature, precipitation, and other climatic variables can affect geographic and ecological distributions of mammals along with patterns of migration, reproduction, and 
foraging behavior (Crump 1996). My study incorporated weather data obtained from the National Park service to examine relationships between climatological variables (average ambient temperature and relative humidity at 0000 and 1200 and total monthly rainfall), and the relative abundance of murid rodents (individuals captured/trap night). I performed a multiple regression (SPSS 1998) using these five weather variables as the independent factors, in order to test the effectiveness and validity of climate variables as predictors of rodent abundance in LPK.

I generated a species accumulation curve to examine the appropriateness of the sampling time, and the effectiveness of the trapping regime in sampling all species present within the study area.

\section{$\underline{\text { Results }}$}

\section{Mark-Recapture}

From August 1998 to August 1999, I sampled during 4,809 trap nights, in four habitat types, and up to seven study locations The trapping yielded a total of 198 captured individuals from four species (Table 5). The cotton mouse (Peromyscus gossypinus) was the most ubiquitous species encountered during trapping, and was captured most often in the hardwood hammocks The cotton rat (Sigmodon hispidus) was the second most abundant species, and was much less common than $P$. gossypinus. The cotton rat was captured most often in the Pinelands, but was also found in all four habitat types. The non-indigenous Black rat (Rattus rattus) was the third most abundant species encountered and was only found in the disturbed area (Hole-in-the-Donut) dominated by 
Table 5. Number of individuals captured of each species within each of the four habitat types and seven study locations. Proportion of total captures is included. Pg (Peromyscus gossypinus), Sh (Sigmodon hispidus), Op (Oryzomys palustris), $\operatorname{Rr}$ (Rattus rattus).

\begin{tabular}{lcccccc}
\hline Habitat & Pg & Sh & Op & Rr & Total & Proportion of Total \\
\hline \hline & & & & & & \\
Ham 1 & 72 & 1 & 0 & 0 & 73 & $\mathbf{0 . 3 6 9}$ \\
Ham 2 & 3 & 1 & 0 & 0 & 4 & 0.02 \\
Pine 1 & 1 & 21 & 0 & 0 & 22 & $\mathbf{0 . 1 1 1}$ \\
Pine 2 & 11 & 38 & 0 & 0 & 49 & $\mathbf{0 . 2 4 7}$ \\
Wet 1 & 1 & 0 & 0 & 0 & 1 & $\mathbf{0 . 0 0 5}$ \\
Wet 2 & 3 & 1 & 8 & 0 & 12 & $\mathbf{0 . 0 6 1}$ \\
Schinus & 13 & 8 & 3 & 13 & 37 & $\mathbf{0 . 1 8 7}$ \\
Total & 104 & 70 & 11 & 13 & $\mathbf{1 9 8}$ & \\
& & & & & & \\
Proportion & $\mathbf{0 . 5 2 5}$ & $\mathbf{0 . 3 5 4}$ & $\mathbf{0 . 0 5 6}$ & $\mathbf{0 . 0 6 6}$ & & \\
of Total & & & & & & \\
& & & & & & \\
\hline \hline
\end{tabular}


the non-native Schinus terebinthifolius. The Marsh-Rice rat (Oryzomys palustris) was, as its name would suggest, found primarily in the marshland sites but a few animals were captured in the Schinus site (Hole-in-the-Donut). Oryzomys palustris was also the least often captured of the four species present in LPK.

The greatest degree of trapping success occurred in the tropical hardwood hammocks, which accounted for $39 \%$ of the total number of individuals captured while representing less than twenty percent of the total sampling effort. The wetland sites were the most barren of the four habitat types accounting for only $6.5 \%$ of the total yield. Wetland 1 was the least populated of the seven study locations, with only one individual captured.

Male individuals accounted for 58 percent of the total captures, with male $P$. gossypinus having the highest frequency of capture (Figure 6). In all species, with the exception of Sigmodon hispidus, males were captured more frequently than females.

The capture of juveniles was relatively rare throughout the study. Juveniles accounted for $26 \%$ of the total capture, but were found in even lower proportions in three of the four species encountered. Only in Sigmodon hispidus were juveniles frequently captured. Juveniles accounted for exactly half of all captures of Sigmodon hispidus. While $P$. gossypinus was the most frequently captured species, juveniles accounted for only $11 \%$ of the total number of captures.

\section{Abiotic factors}

In the one-way, fixed factors repeated measures ANOVA, I found no significant effect due to temporal variation across all habitat types $\left(\mathrm{F}_{11,22}=1.33, p=0.273\right)$. 


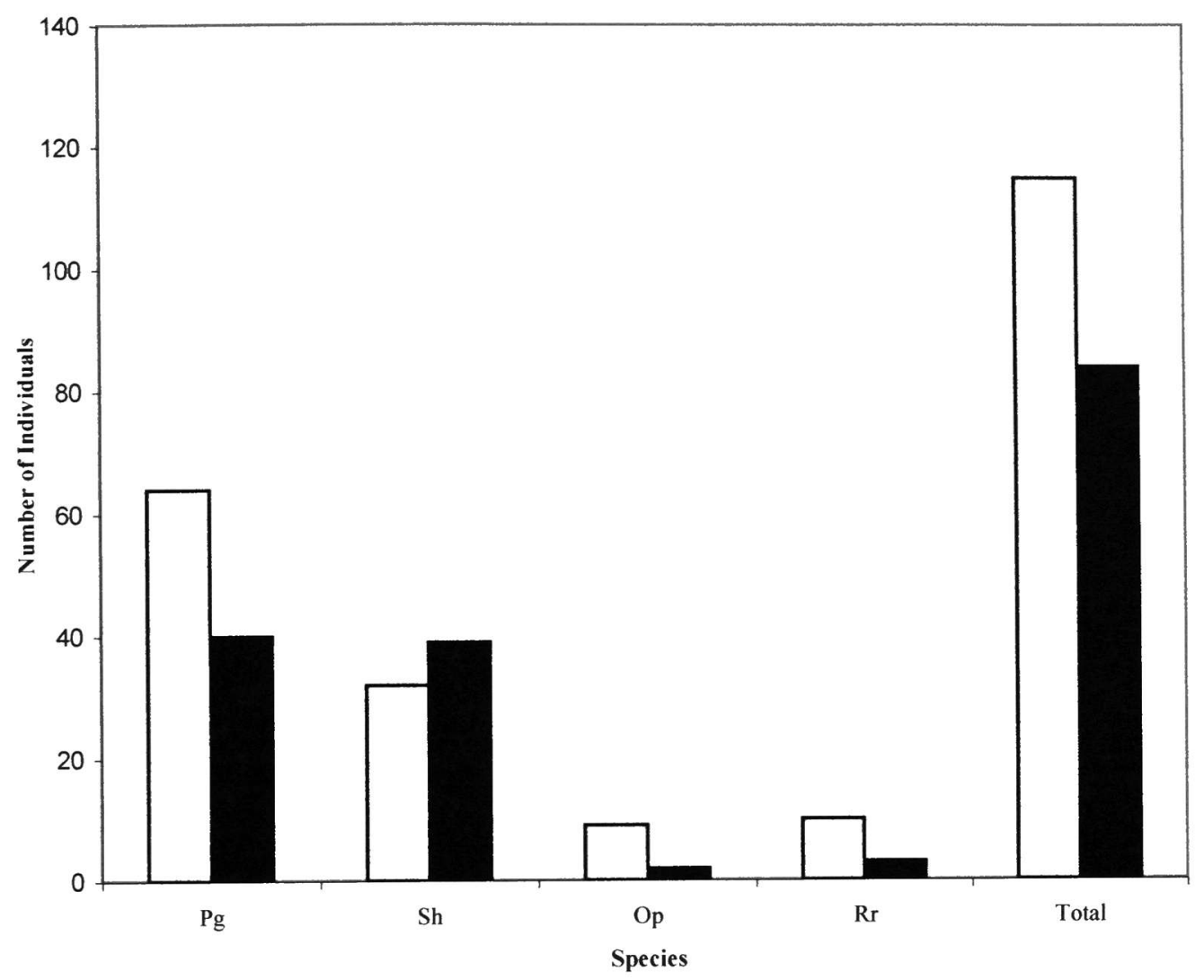

Figure 6. Total number of males and females of each, and total number of males and females of all species combined. Dark bars represent females; Gray bars represent males. 
The abundance of $P$. gossypinus was greater in the hammocks than in any other habitat type during every sampling period (Figure 7). The number of $P$. gossypinus was greatest during the month of October and was at its lowest point in August 1998, and August 1999. The general trend for this species in the hardwood hammock was a peak during the early winter months, and a decline during the summer rainy season. The number of $P$. gossypinus captured in the Schinus remained relatively constant throughout the year. Sigmodon hispidus was found in the pinelands every month of the year with the exception of August 1998, and August 1999 when it was presumably driven out of the study areas by prescription burns (Figure 8). The abundance of Rattus rattus peaked during October and January, but individuals were remarkably absent from traps during December 1998 and June 1999 (Figure 9). Oryzomys palustris was never captured in Wetland 1 (sparsely vegetated finger glade), and was conspicuously absent from the wetlands during the summer months of July and August, when many prairies were burned (Figure 10). However, Oryzomys palustris was present in the Schinus during these months.

Males accounted for more than $50 \%$ of the total capture in ten out of twelve months (Figure 11). Males of $P$. gossypinus were more abundant during every sampling period with the exception of August 1998, when only two females of this species were captured (Figure 12). Females of $S$. hispidus tended to be more abundant than males throughout the year, with female and overall abundance peaking during March, and declining during the summer months (Figure 13). Females of Oryzomys palustris were absent during the March and June sampling periods, with male and overall abundance 


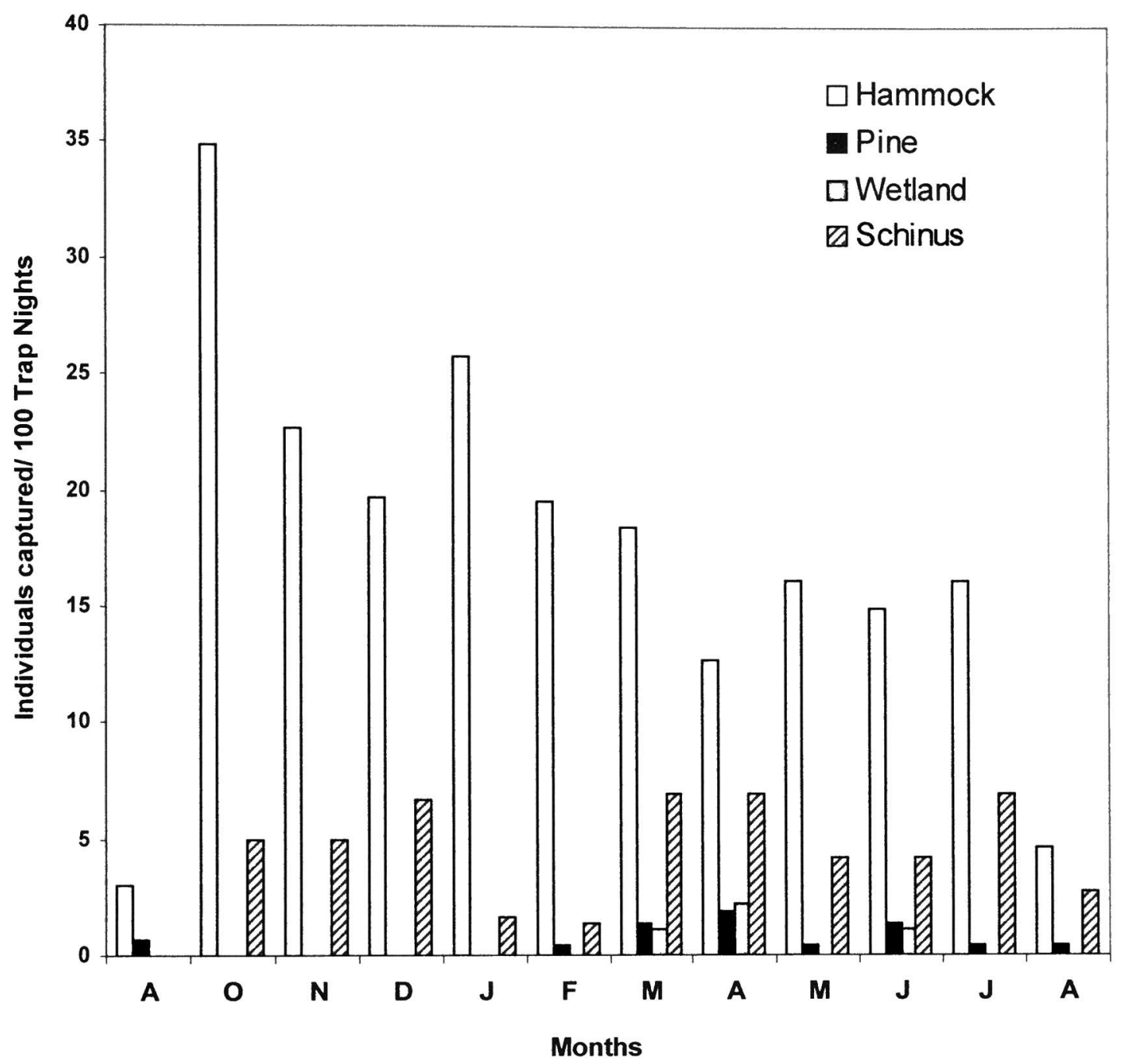

Figure 7. Monthly abundance of Peromyscus gossypinus in all habitats. 


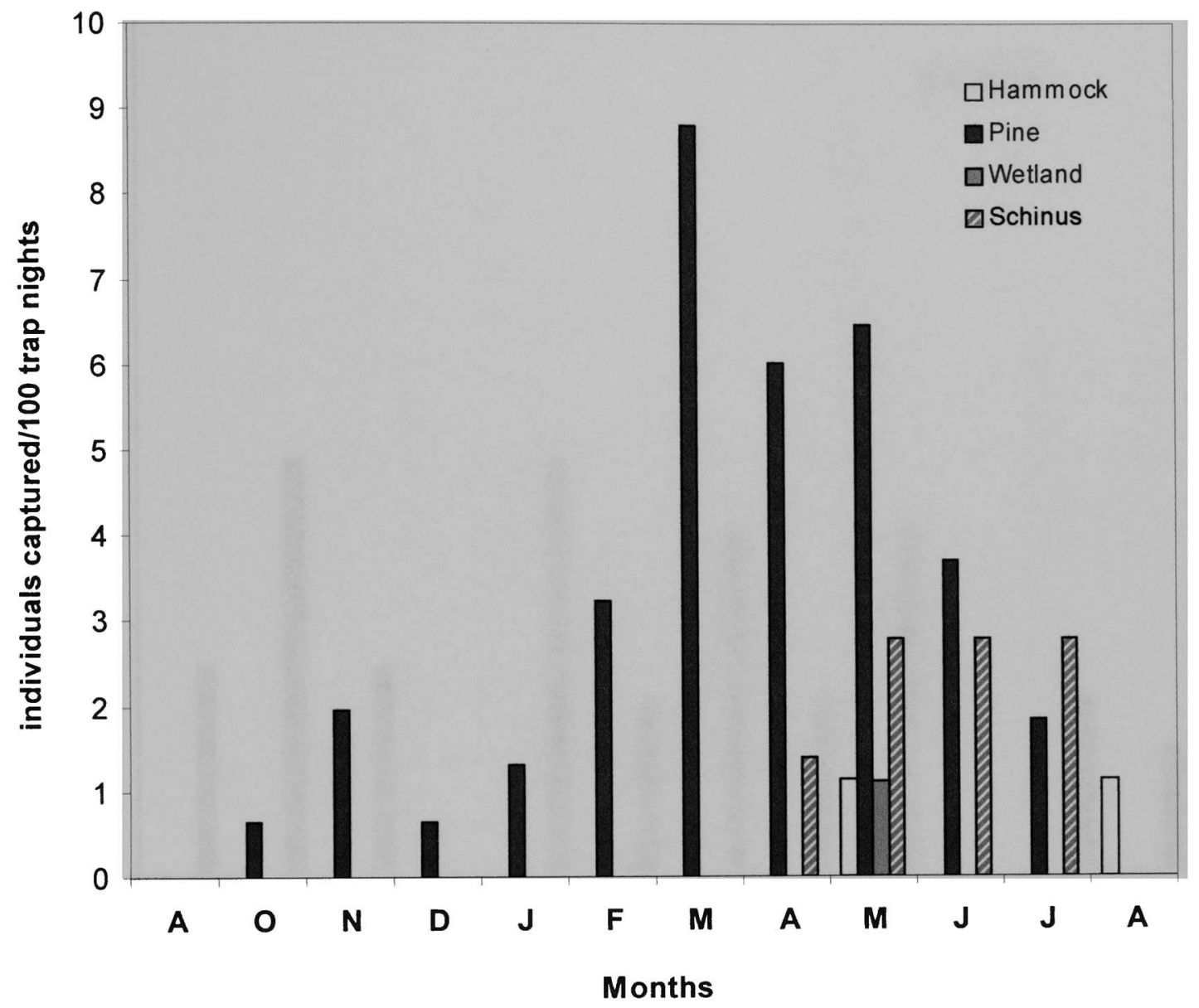

Figure 8. Monthly abundance of Sigmodon hispidus in all habitats where it occurs. 


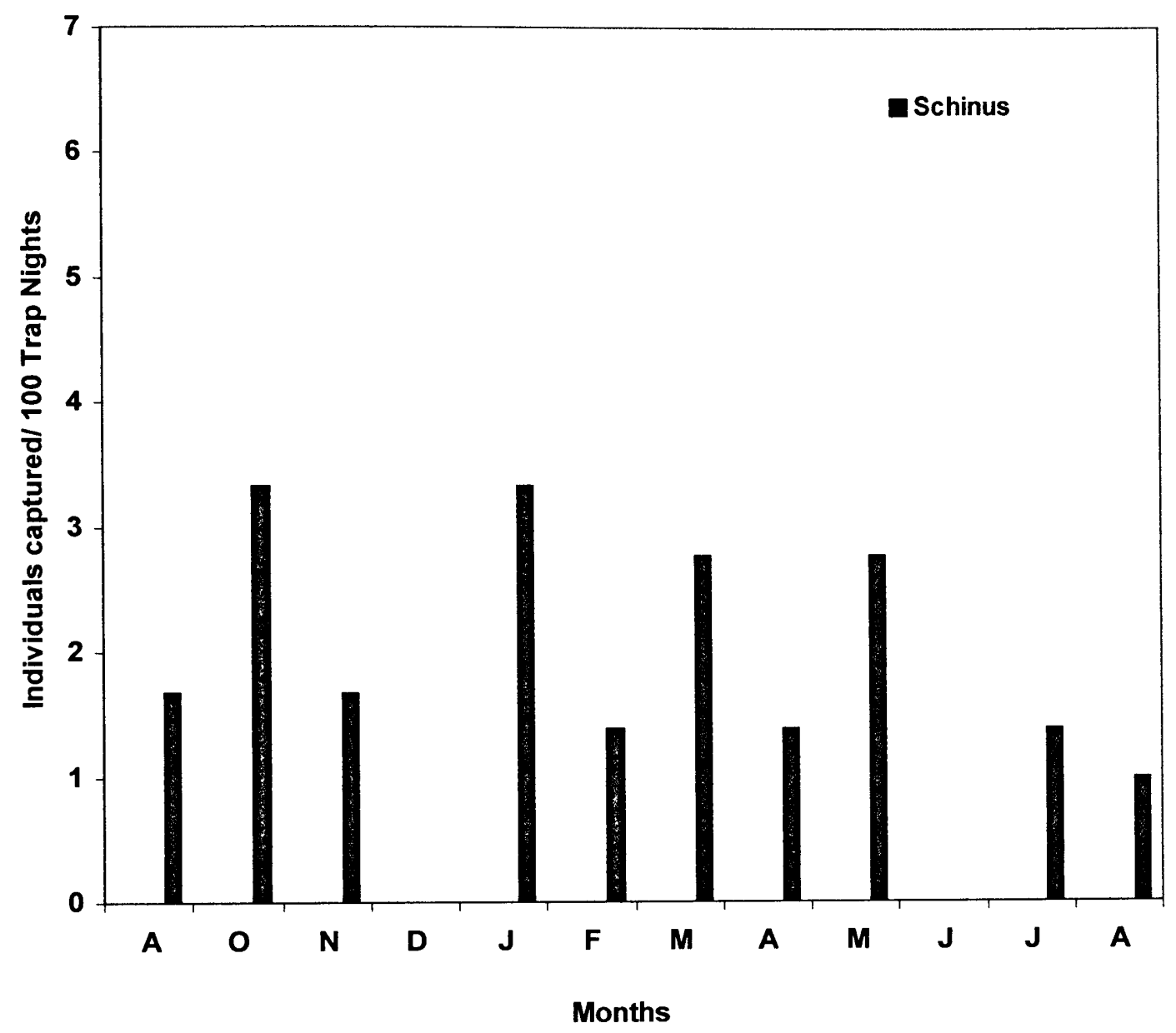

Figure 9. Monthly abundance Rattus rattus in Schinus terebinthifolius. 


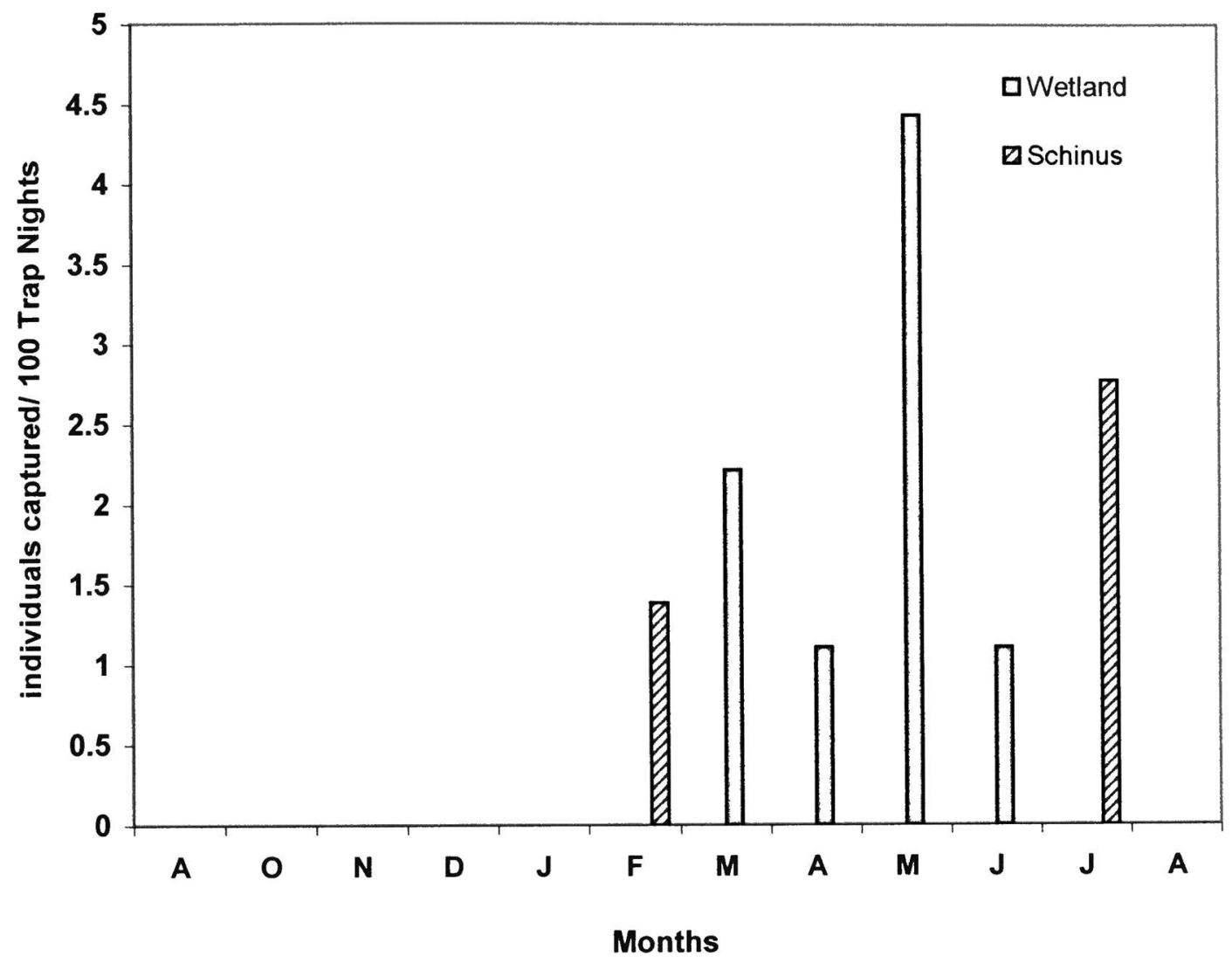

Figure 10. Monthly abundance of Oryzomys palustris in all habitats where it occurs. 


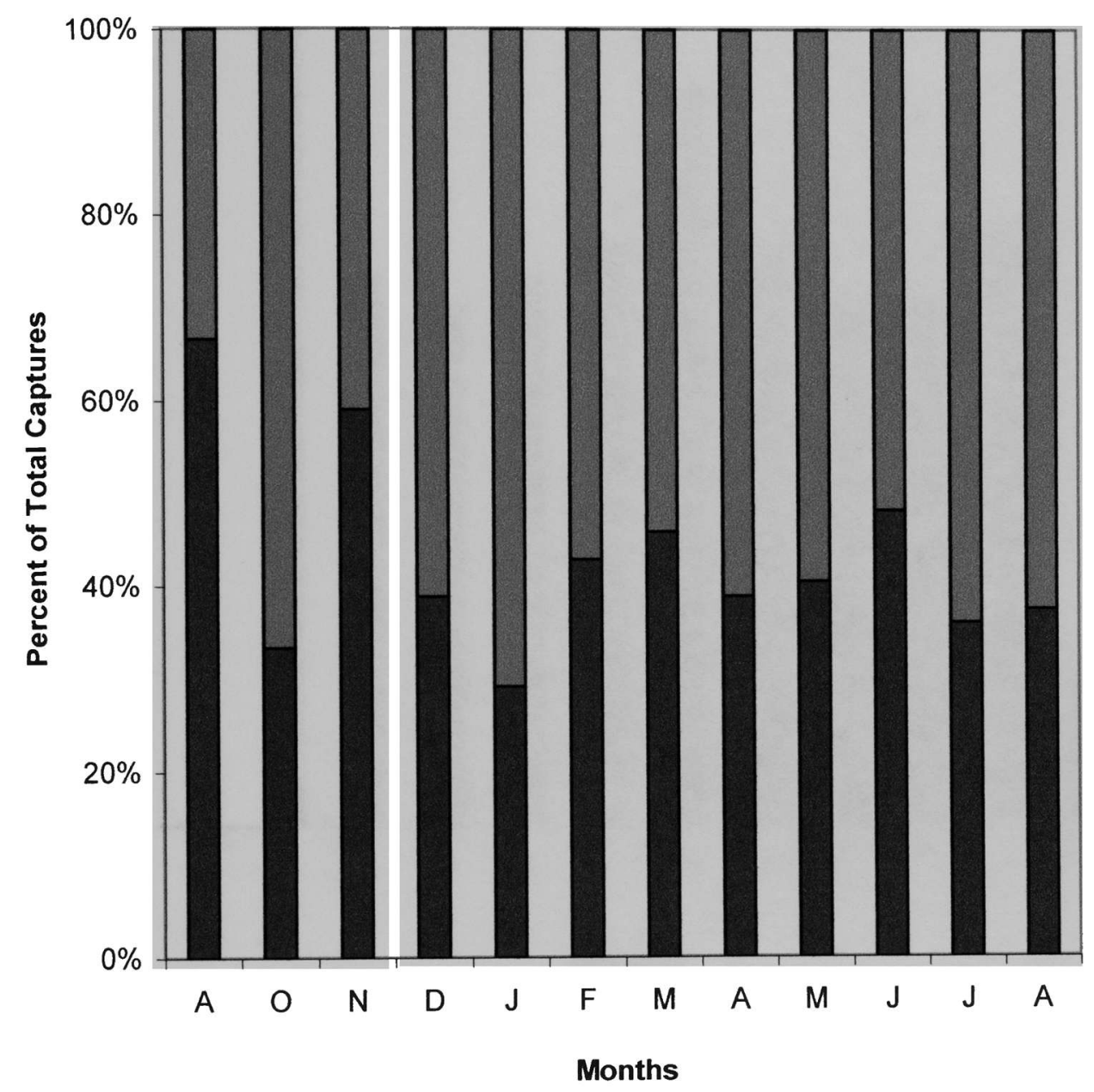

Figure 11. Percent male and female captured (total) per month. Dark bars represent female captures; Gray bars represent male captures. 


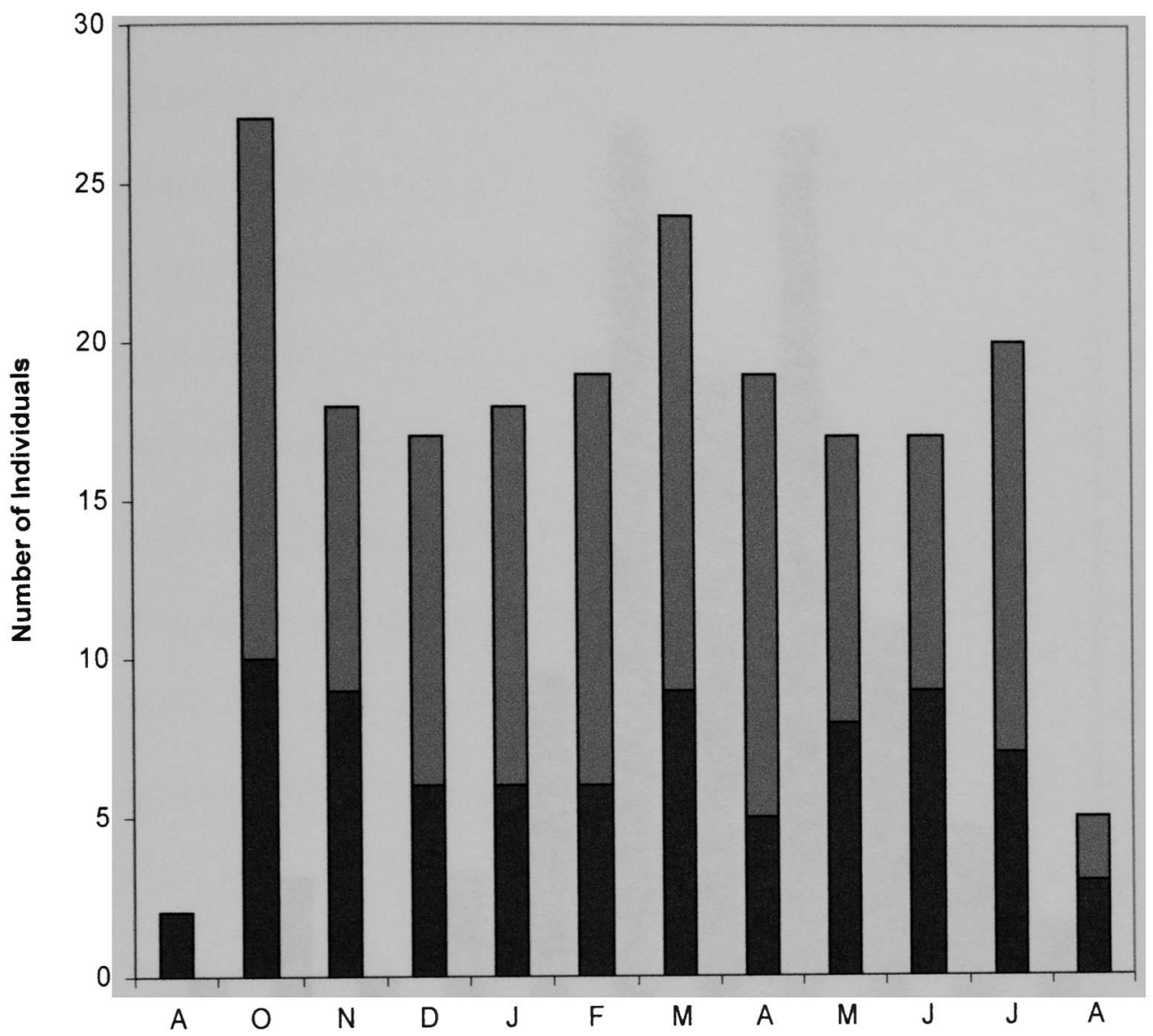

Months

Figure 12. Number of males and females of $P$. gossypinus captured per month. Dark bars represent female captures; Gray bars represent male captures. 


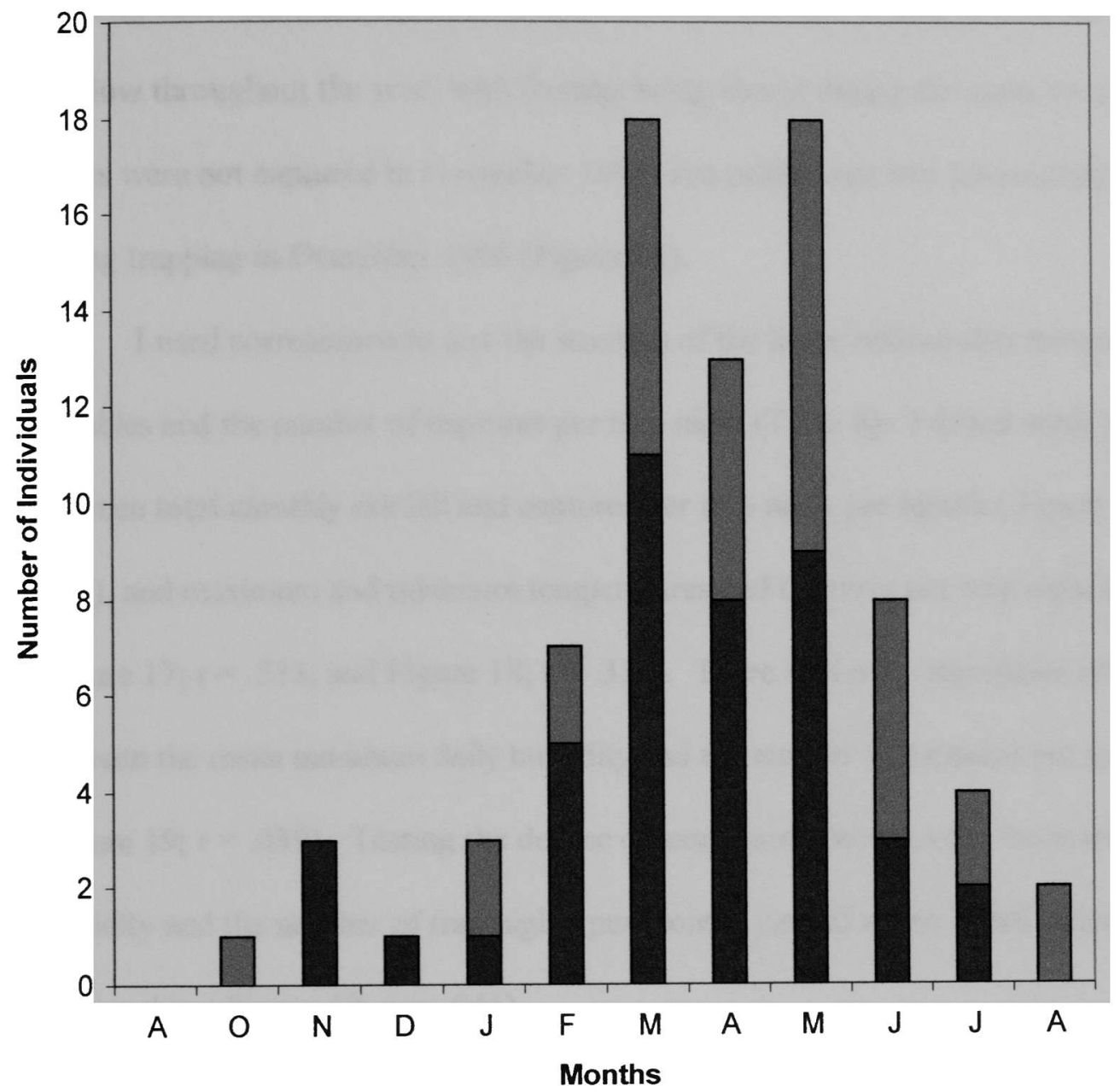

Figure 13. Number of male and female Sigmodon hispidus captured per month. Dark bars represent female captures; Gray bars represent male captures. 
reaching their zenith in May 1999 (Figure 14). Abundance of male and female R. rattus was low throughout the year, with females being absent during the summer months. Males were not captured in November 1998, and neither sex was successfully captured during trapping in December 1998 (Figure 15).

I used correlations to test the strength of the linear relationship between weather variables and the number of captures per trap night (Table 6). I found weak associations between total monthly rainfall and captures per trap night per month ( Figure 16; $r=$ .263 ), and maximum and minimum temperatures and captures per trap night per month (Figure $17 ; \mathrm{r}=.313$, and Figure $18 ; \mathrm{r}=.314$ ). There was not a significant relationship between the mean minimum daily humidity and the number of captures per trap night (Figure $19 ; \mathrm{r}=.039$ ). Testing the degree of association between the mean maximum daily humidity and the number of trap nights per months yielded a very weak, negative relationship ( Figure 20; r $=-.041$ ).

I conducted a multiple regression analysis in order to test the effectiveness of combining weather variables to be used as predictors of rodent abundance in LPK. I found no significant relationship between the five weather variables used as predictors, and the measure of rodent abundance $\left(F_{5,63}=.287, \mathrm{p}=0.898\right.$, and $\left.\mathrm{R}^{2}=.264\right)$. Taking into account the number of predictors used in the regression equation the resultant adjusted $R^{2}$ $=-.656$. 


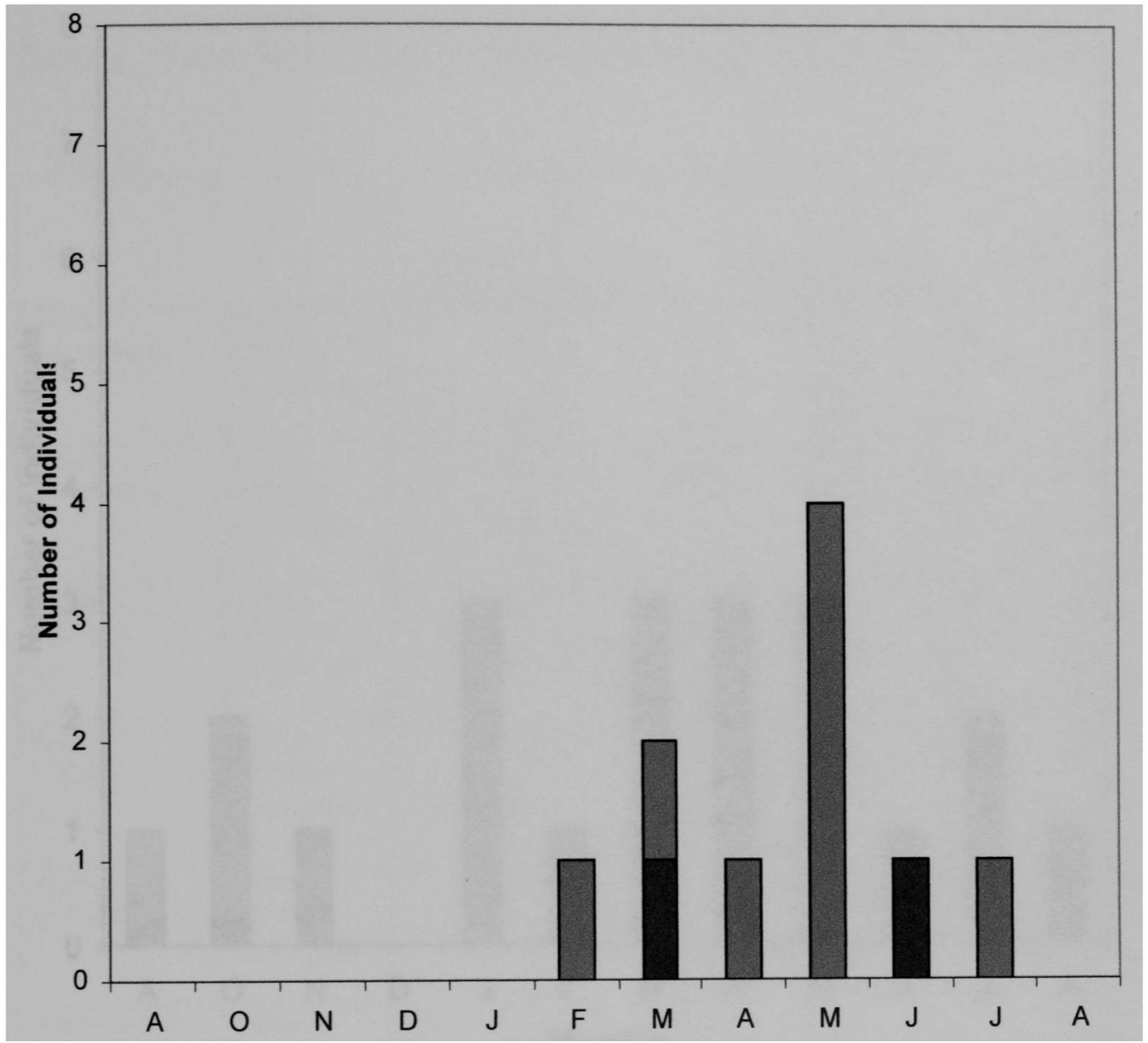

Months

Figure 14. Number of male and female Oryzomys palustris captured per month. Dark bars represent female captures; Gray bars represent male captures. 


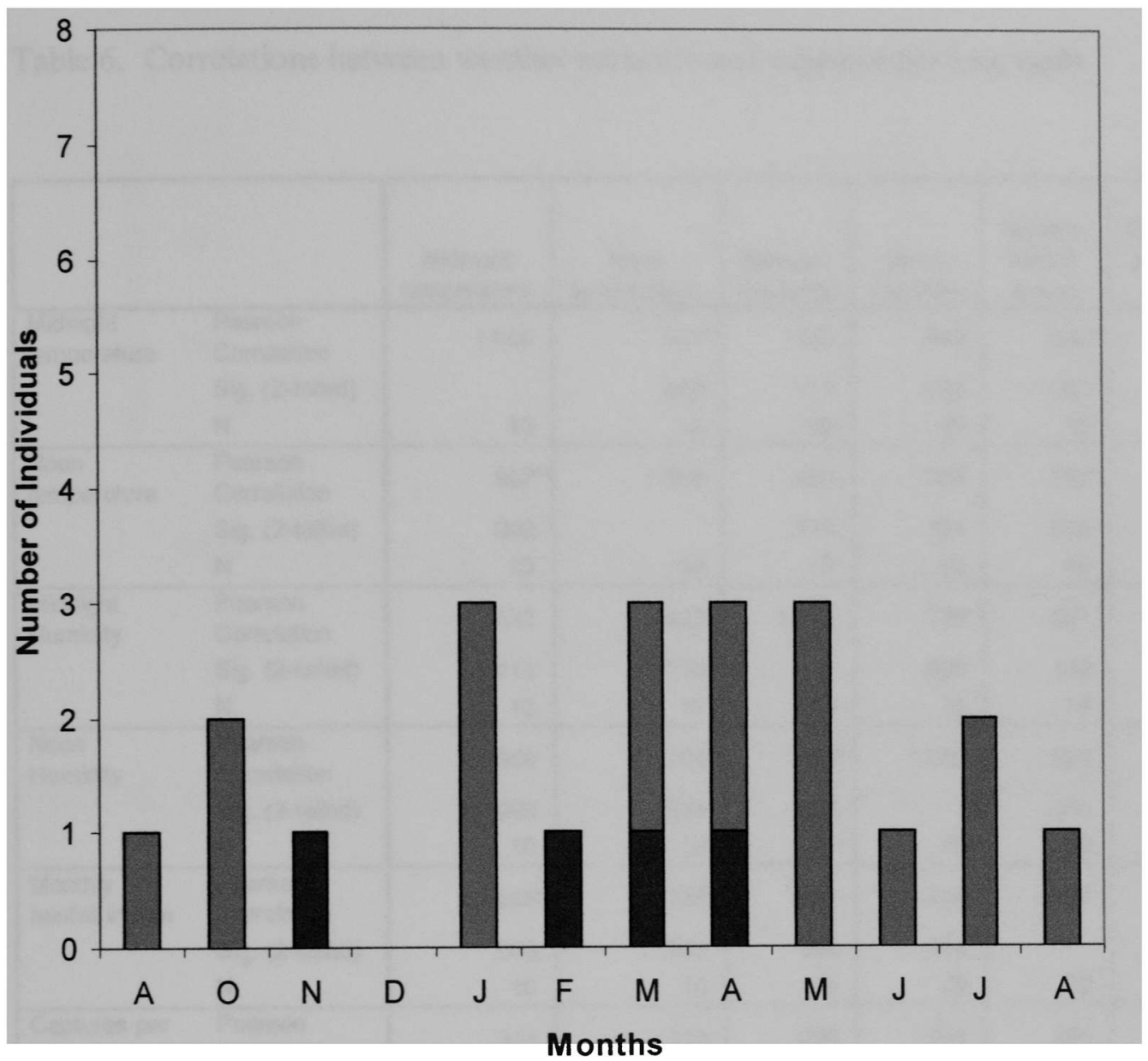

Figure 15. Number of males and females of Rattus rattus captured per month. Dark bars represent female captures; Gray bars represent male captures. 
Table 6. Correlations between weather variables and captures per trap night.

\begin{tabular}{|c|c|c|c|c|c|c|c|}
\hline & & $\begin{array}{c}\text { Midnight } \\
\text { temperature }\end{array}$ & $\begin{array}{c}\text { Noon } \\
\text { temperature }\end{array}$ & $\begin{array}{l}\text { Midnight } \\
\text { Humidity }\end{array}$ & $\begin{array}{c}\text { Noon } \\
\text { Humidity }\end{array}$ & $\begin{array}{l}\text { Monthly } \\
\text { rainfall } \\
\text { in } \mathrm{mm}\end{array}$ & $\begin{array}{l}\text { Captures } \\
\text { per trap } \\
\text { night }\end{array}$ \\
\hline \multirow[t]{3}{*}{$\begin{array}{l}\text { Midnight } \\
\text { temperature }\end{array}$} & $\begin{array}{l}\text { Pearson } \\
\text { Correlation }\end{array}$ & 1.000 & $.937^{\star *}$ & .533 & 550 & $.828^{\star}$ & .314 \\
\hline & Sig. (2-tailed) & & .000 & .113 & .099 & .003 & .377 \\
\hline & $\mathbf{N}$ & 10 & 10 & 10 & 10 & 10 & 10 \\
\hline \multirow[t]{3}{*}{$\begin{array}{l}\text { Noon } \\
\text { temperature }\end{array}$} & $\begin{array}{l}\text { Pearson } \\
\text { Correlation }\end{array}$ & $.937^{* *}$ & 1.000 & .429 & .304 & $.751^{\star}$ & .313 \\
\hline & Sig. (2-tailed) & .000 & & .216 & .394 & .012 & .379 \\
\hline & $\mathbf{N}$ & 10 & 10 & 10 & 10 & 10 & 10 \\
\hline \multirow[t]{3}{*}{$\begin{array}{l}\text { Midnight } \\
\text { Humidity }\end{array}$} & $\begin{array}{l}\text { Pearson } \\
\text { Correlation }\end{array}$ & .533 & .429 & 1.000 & $.770^{\star *}$ & .501 & .039 \\
\hline & Sig. (2-tailed) & .113 & .216 & & .009 & 140 & .914 \\
\hline & $\mathbf{N}$ & 10 & 10 & 10 & 10 & 10 & 10 \\
\hline \multirow[t]{3}{*}{$\begin{array}{l}\text { Noon } \\
\text { Humidity }\end{array}$} & $\begin{array}{l}\text { Pearson } \\
\text { Correlation }\end{array}$ & .550 & .304 & $.770^{* 4}$ & 1.000 & .624 & -.041 \\
\hline & Sig. (2-tailed) & .099 & 394 & .009 & & .054 & .911 \\
\hline & $\mathbf{N}$ & 10 & 10 & 10 & 10 & 10 & 10 \\
\hline \multirow[t]{3}{*}{$\begin{array}{l}\text { Monthly } \\
\text { rainfall in } \mathrm{mm}\end{array}$} & $\begin{array}{l}\text { Pearson } \\
\text { Correlation }\end{array}$ & $.828^{* \star}$ & $.751^{*}$ & .501 & .624 & 1.000 & .263 \\
\hline & Sig. (2-tailed) & .003 & .012 & .140 & .054 & & .462 \\
\hline & $\mathbf{N}$ & 10 & 10 & 10 & 10 & 10 & 10 \\
\hline \multirow[t]{3}{*}{$\begin{array}{l}\text { Captures per } \\
\text { trap night }\end{array}$} & $\begin{array}{l}\text { Pearson } \\
\text { Correlation }\end{array}$ & .314 & .313 & .039 & -.041 & .263 & 1.000 \\
\hline & Sig. (2-tailed) & .377 & .379 & .914 & .911 & .462 & . \\
\hline & $N$ & 10 & 10 & 10 & 10 & 10 & 10 \\
\hline
\end{tabular}

${ }^{* *}$. Correlation is significant at the 0.01 level (2-tailed).

*. Correlation is significant at the 0.05 level (2-tailed). 


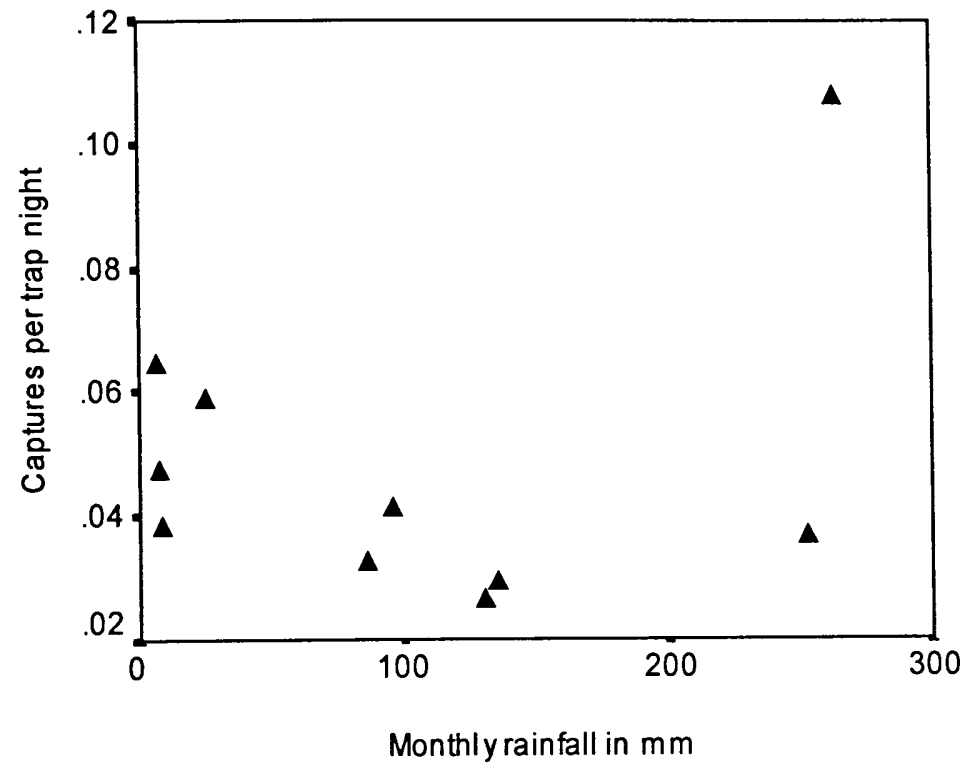

Figure 16. Scatter plot of total monthly rainfall and captures per trap night.

50 


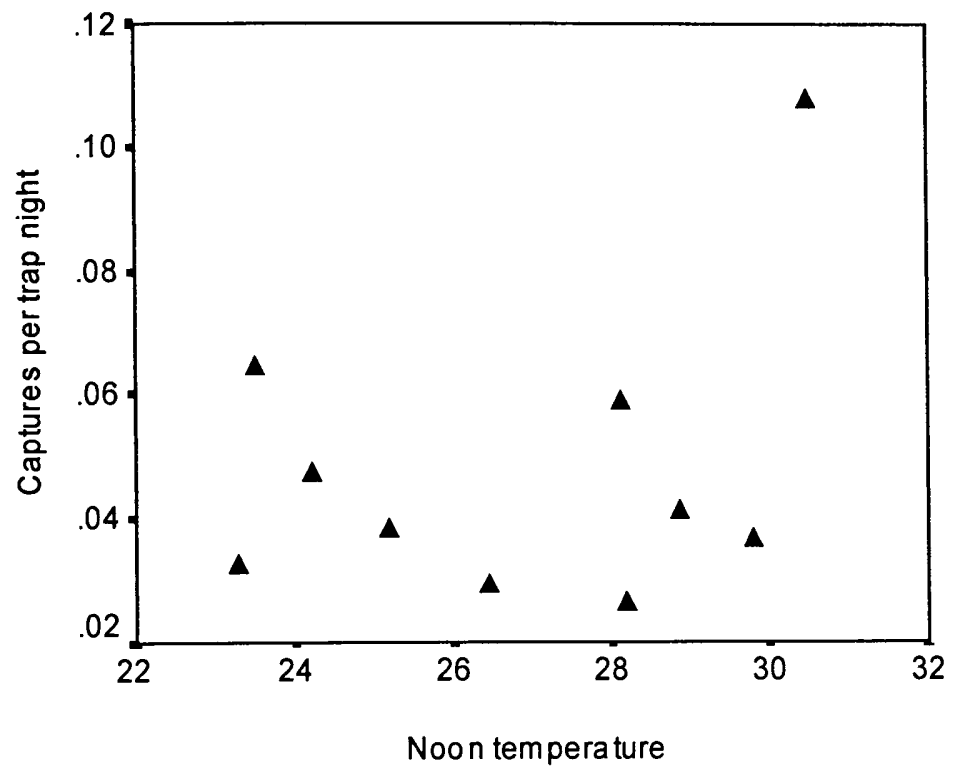

Figure 17. Scatter plot of maximum temperature and captures per trap night. 


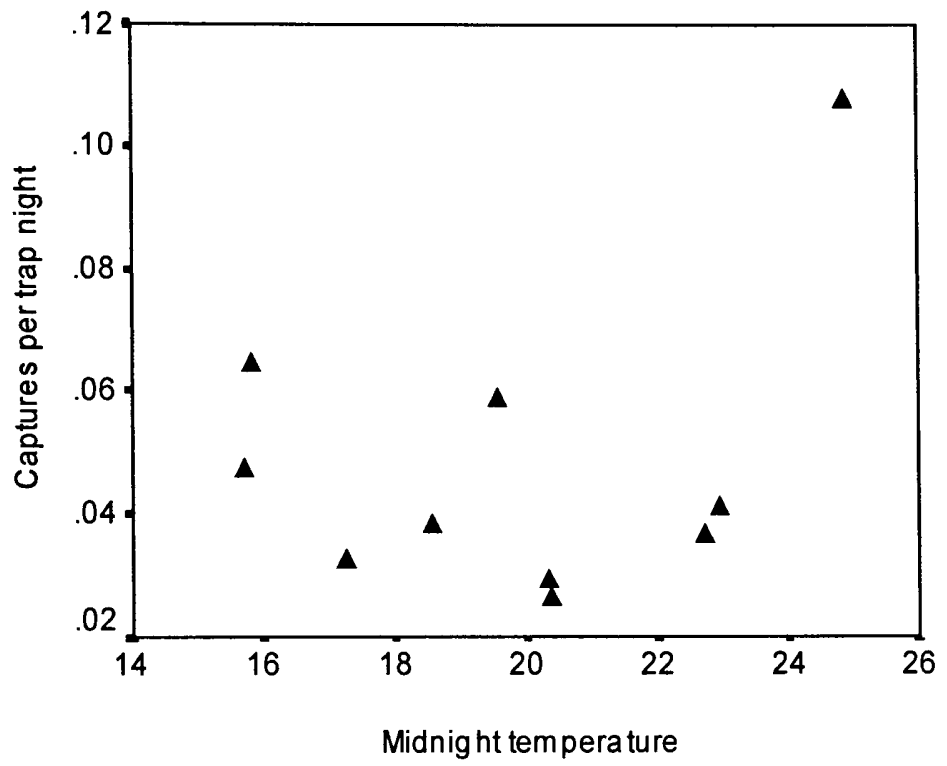

Figure 18. Scatter plot of midnight temperature and captures per trap night. 


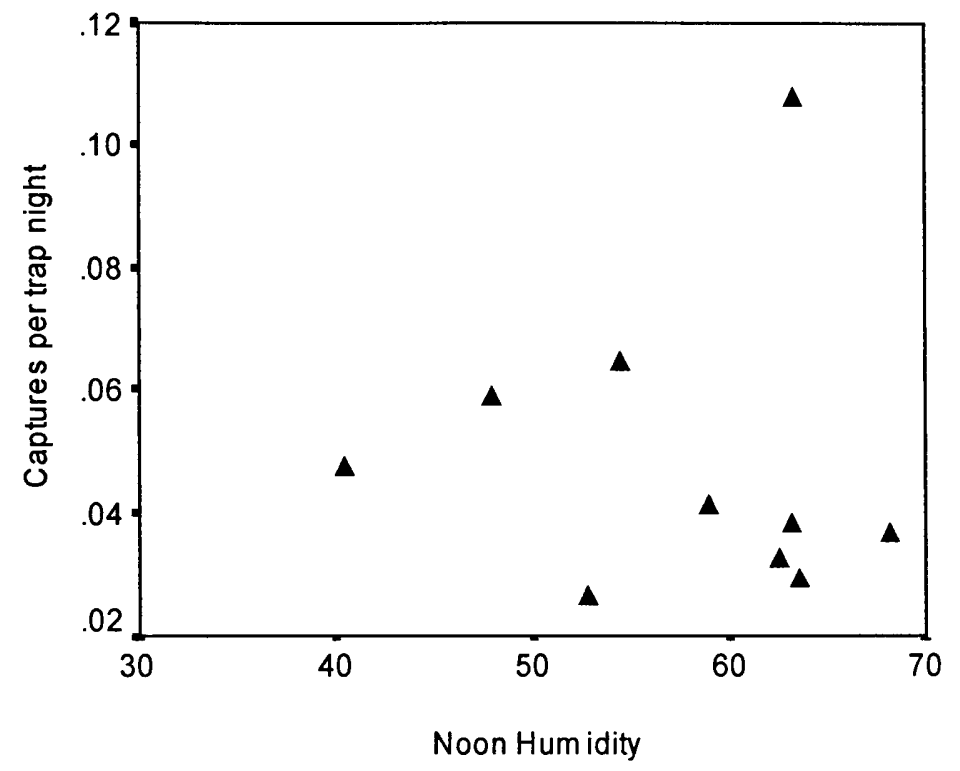

Figure 19. Scatter plot of noon humidity and captures per trap night. 


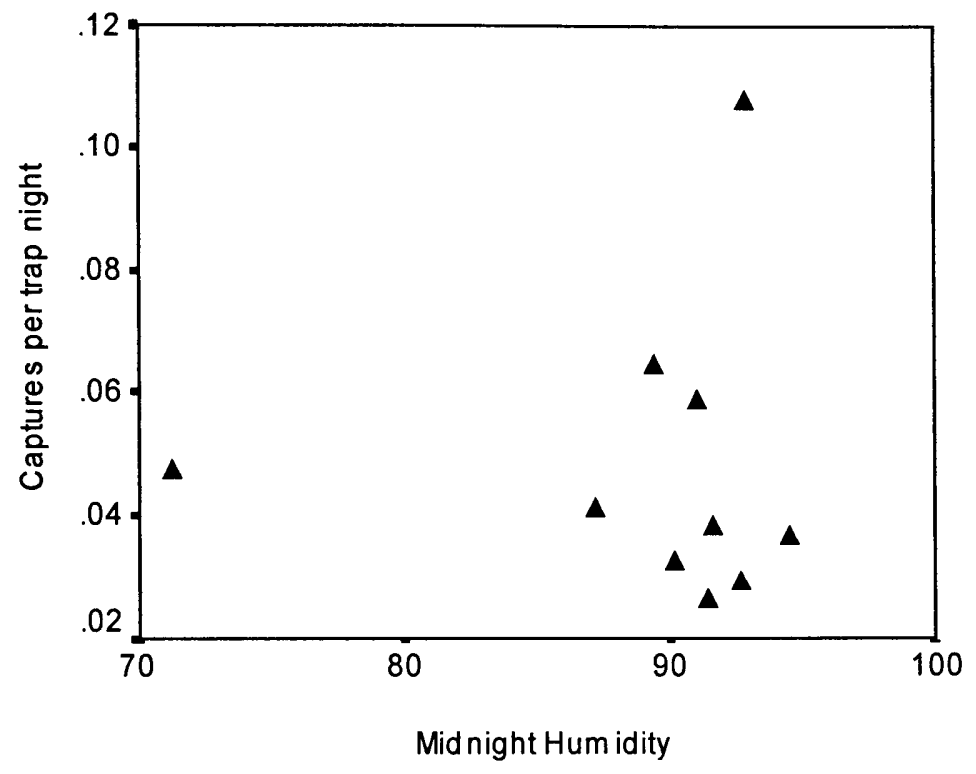

Figure 20. Scatter plot of maximum daily humidity and captures per trap night. 


\section{Vegetational Analysis}

Vegetation characterizations were conducted in the four study locations with open canopies and well developed herbaceous layers. Pineland 2 was more thickly vegetated than Pineland 1, with mean percent cover ratings of 3.2 (41-60\%), and 4 (61-80\%) respectively. Pineland 2 also had had a greater proportion of points (40\%) having woody vegetation in heights of $2 \mathrm{~m}$ or higher. Only one of twenty points measured in Pineland 1 (measurements in Pineland 1 occurred in November 1998, and March 1999) exhibited vegetation in excess of $2 \mathrm{~m}$ in height. The observations of vegetational characteristics in the wetlands also exhibited noticeable differences between the two study locations.

Wetland 1 was sparsely vegetated in both sampling occasions with mean percent cover scores of $2.8(31-40 \%)$, and $3.0(41-60 \%)$, while Wetland 2 was noticeably denser with a mean percent cover score of $4.0(61-80 \%)$.

\section{Sampling Effort}

The 4,809 total trap nights over a 12 month period were sufficient to adequately sample the rodent populations of LPK. After repeated sampling no more than 4 species were captured inducing a flat-line in the species accumulation curve (Figure 21).

\section{Estimation of Population Size}

The Method B table (Appendix 1) computed from the mark-recapture history of $P$. gossypinus in the tropical hardwood hammock shows that a total of 72 individuals were captured over 12 sampling periods. Using Method B table data, I obtained Jolly-Seber population size estimates $(N)$, the proportion of animals marked $(\alpha)$, the estimated size of the marked population $(M)$, and an estimated probability of survival for each sampling 


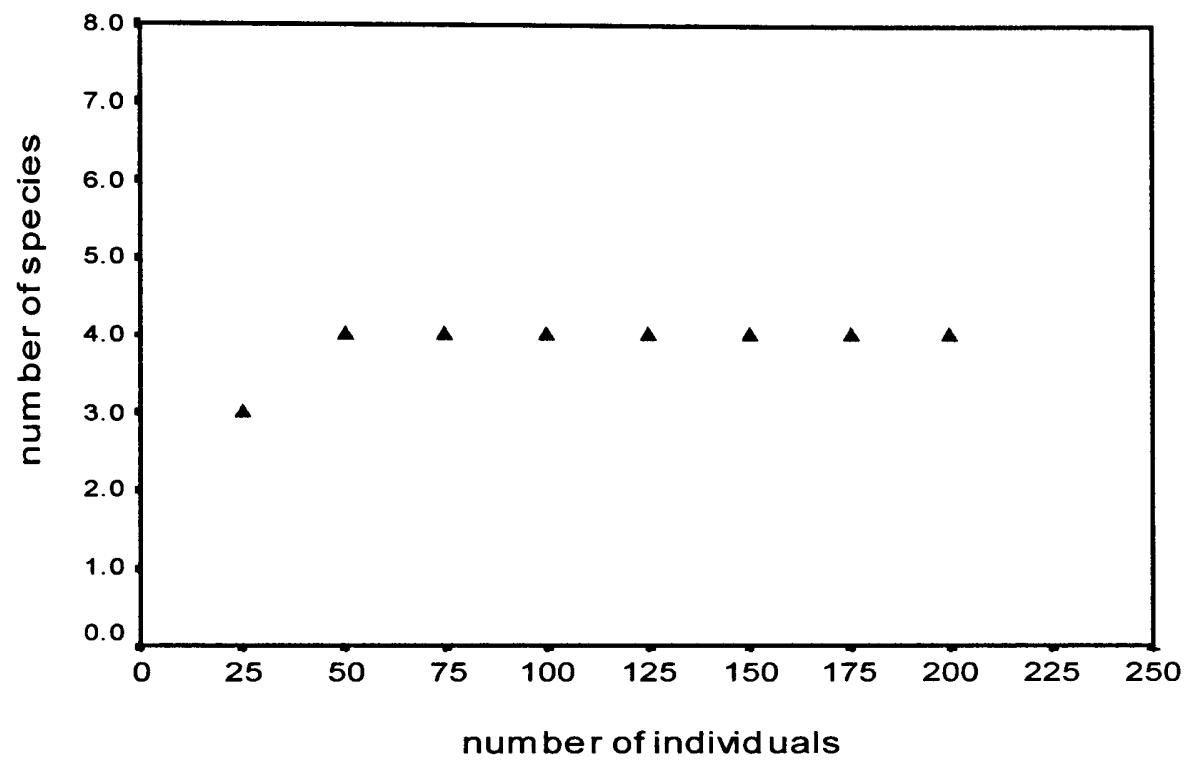

Figure 21. Species accumulation curve generated using all capture data. 
occasion (Table 7). I also calculated these four population estimates derived from markrecapture histories, outlined in respective Method B tables, for Sigmodon hispidus in Pineland 1 (Table 8), S. hispidus in Pineland 2 (Tables 9), P. gossypinus in the Hole-inthe-Donut (Table 10), and Rattus rattus also in the Hole-in-the-Donut area (Table 11).

In almost all cases, the population size estimated by the Jolly-Seber method oscillated widely from sampling period to sampling period. The estimate was particularly variable in those cases where few total animals were captured, and during periods where the number of recaptures was also low. Confidence intervals for the population size estimate $(N)$, and the probability of survival $(\Phi)$ could not be calculated due to the small number of captures that frequently led to unfeasible mathematical calculations such as, taking the square root of negative numbers, and zeroes present in numerators. For these reasons an alternate estimate of population size within each study location was conducted using the minimum number alive of a particular species at any given point to be used as a standard of comparison to the Jolly-Seber estimate. The minimum number alive method generated consistently more stable estimates of population size, but in cases where the number of individuals captured or marked was low, the minimum number alive also resulted in an unnaturally low population estimate.

Peromyscus gossypinus proved to have the highest density of the four species captured, throughout the duration of the study (Figure 22). The biased density estimates I obtained by dividing the minimum number alive by the size of the trapping area in all cases yielded significantly higher estimates than the corrected estimates I obtained using the Bondrup-Nielsen Boundary Strip Method, taking into account the home range size of each 
Table 7. Table of total population estimates for Peromyscus gossypinus derived from Jolly-Seber method (Krebs 1999) and Minimum Number Alive. Alpha is proportion of animals marked; $M$ is estimate of size of marked population; $N$ is estimate of total population; Prob. Surv. is the probability of an individual surviving to the next sampling period.

\begin{tabular}{cccccc}
\hline Month & $\boldsymbol{\alpha}$ & $\boldsymbol{M}$ & $\boldsymbol{N}$ & \multicolumn{2}{c}{ Prob. Surv. Min. \# Alive } \\
\hline & & & & & \\
Aug-98 & 0.333 & 3 & 0 & 0 & 2 \\
Oct-98 & 0.042 & 0 & 0 & 0.217 & 23 \\
Nov-98 & 0.375 & 6.6 & 17.83 & 0.467 & 15 \\
Dec-98 & 0.533 & 12 & 22.6 & 0.615 & 16 \\
Jan-99 & 0.5 & 12.2 & 24.4 & 0.765 & 20 \\
Feb-99 & 0.778 & 15.6 & 20 & 0.706 & 19 \\
Mar-99 & 0.765 & 16 & 21 & 0.667 & 19 \\
Apr-99 & 0.917 & 15.3 & 16.6 & 0.818 & 15 \\
May-99 & 0.667 & 13.5 & 20.15 & 0.714 & 17 \\
Jun-99 & 0.786 & 13.5 & 17.1 & 0.692 & 15 \\
Jul-99 & 0.667 & 9 & 13.4 & 0.143 & 14 \\
Aug-99 & 0.75 & & & & 3 \\
& & & & & \\
\hline \hline
\end{tabular}


Table 8. Table of total population estimates for Sigmodon hispidus in Pineland 1,derived from Jolly-Seber method (Krebs 1999) and Minimum Number Alive. Alpha $(\alpha)$ is proportion of animals marked; $M$ is estimated size of marked population; $N$ is estimated size of total population; Prob. Surv. is the probability of an individual surviving to the next sampling period.

\begin{tabular}{cccccc|}
\hline \multicolumn{1}{c}{ Month } & $\alpha$ & $M$ & $N$ & Prob of Surv. & $\begin{array}{c}\text { Min. \# } \\
\text { Alive }\end{array}$ \\
\hline \hline & & & & & \\
Aug-98 & 0 & 0 & 0 & 0 & 0 \\
Oct-98 & 1 & & & 0 & 0 \\
Nov-98 & 0.5 & 0 & 0 & 0 & 1 \\
Dec-98 & 0.2 & 0 & 0 & 0 & 4 \\
Jan-99 & 0.25 & 0 & 0 & 1 & 1 \\
Feb-99 & 0.5 & 1 & 2 & 0.5 & 3 \\
Mar-99 & 0.33 & 1.5 & 4.55 & 0.571 & 3 \\
Apr-99 & 0.33 & 2 & 6 & 0.188 & 8 \\
May-99 & 0.17 & 1.5 & 8.82 & 0.615 & 6 \\
Jun-99 & 0.83 & 4 & 4.82 & 0.286 & 5 \\
Jul-99 & 0.66 & 1 & 1.52 & & 2 \\
Aug-99 & & 0 & 0 & 0 & 0 \\
& & & & \\
\hline \hline
\end{tabular}


Table 9. Table of total population estimates for Sigmodon hispidus in Pineland 2 derived from Jolly-Seber method (Krebs 1999) and Minimum Number Alive. Alpha is proportion of animals marked; $M$ is estimate of size of marked population; $N$ is estimate of total population; Prob. Surv. is the probability of an individual surviving to the next sampling period.

\begin{tabular}{cccccc}
\hline Month & $\alpha$ & $M$ & $N$ & Prob. Surv. & $\begin{array}{c}\text { Min \# } \\
\text { Alive }\end{array}$ \\
\hline \hline & & & & & \\
Feb-99 & 0.167 & 0 & 0 & 1 & 5 \\
Mar-99 & 0.286 & 3 & 10.49 & 0.367 & 13 \\
Apr-99 & 0.4 & 5.5 & 13.75 & 1 & 10 \\
May-99 & 0.357 & 14.4 & 40.34 & 0.179 & 13 \\
Jun-99 & 0.625 & 4 & 6.4 & 0 & 8 \\
Jul-99 & 0.2 & 0 & 0 & 0 & 4 \\
Aug-99 & 1 & 0 & 0 & 0 & 0 \\
& & & & & \\
\hline \hline
\end{tabular}


Table 10. Table of total population estimates for Peromyscus gossypinus in the Hole-inthe- Donut, derived from Jolly-Seber method (Krebs 1999) and Minimum Number Alive. Alpha is proportion of animals marked; $M$ is estimate of size of marked population; $N$ is estimate of total population; Prob. Surv. is the probability of an individual surviving to the next sampling period.

\begin{tabular}{cccccc}
\hline Month & $\boldsymbol{\alpha}$ & $\boldsymbol{M}$ & $\boldsymbol{N}$ & Prob. Surv. & Min \# Alive \\
\hline \hline & & & & & \\
Aug-98 & 1 & 0 & 0 & 0 & 0 \\
Oct-98 & 0.25 & 0 & 0 & 0.667 & 3 \\
Nov-98 & 0.75 & 2 & 2.67 & 0.25 & 3 \\
Dec-98 & 0.4 & 1 & 2.5 & 1 & 4 \\
Jan-99 & 0.5 & 2 & 4 & 1 & 3 \\
Feb-99 & 0.5 & 3 & 6 & 1 & 4 \\
Mar-99 & 0.667 & 4.5 & 6.75 & 0.692 & 6 \\
Apr-99 & 0.833 & 5.5 & 6.6 & 0.666 & 6 \\
May-99 & 1 & 4.33 & 4.33 & 0.563 & 4 \\
Jun-99 & 0.75 & 3 & 4 & 1 & 4 \\
Jul-99 & 0.833 & 4 & 4.8 & & 5 \\
Aug-99 & 1 & & & & 2 \\
& & & & & \\
\hline \hline
\end{tabular}


Table 11. Table of total population estimates for Rattus rattus in the Hole-in-the- Donut, derived from Jolly-Seber method (Krebs 1999) and Minimum Number Alive. Alpha is proportion of animals marked; $\mathrm{M}$ is estimate of size of marked population; $\mathrm{N}$ is estimate of total population; Prob. Surv. is the probability of an individual surviving to the next sampling period.

\begin{tabular}{cccccc}
\hline Month & $\boldsymbol{\alpha}$ & $\boldsymbol{M}$ & $\boldsymbol{N}$ & Prob. Surv. & $\begin{array}{c}\text { Min. \# } \\
\text { Alive }\end{array}$ \\
\hline \hline & & & & & \\
Aug-98 & 0.5 & 0 & 0 & 1 & 1 \\
Oct-98 & 0.667 & 1 & 1.5 & 1 & 2 \\
Nov-98 & 0.5 & 2 & 4 & 0.333 & 2 \\
Dec-98 & 1 & 1 & 1 & 1 & 1 \\
Jan-99 & 0.5 & 1 & 2 & 0 & 3 \\
Feb-99 & 0.5 & 0 & 0 & 1 & 1 \\
Mar-99 & 0.5 & 1 & 2 & 0.667 & 3 \\
Apr-99 & 0.75 & 2 & 2.67 & 0.777 & 3 \\
May-99 & 0.5 & 2.33 & 4.66 & 1 & 4 \\
Jun-99 & 1 & 5 & 5 & 0.2 & 3 \\
Jul-99 & 0.667 & 1 & 1.5 & 0 & 2 \\
Aug-99 & 1 & & & & 1 \\
& & & & & \\
\hline \hline
\end{tabular}




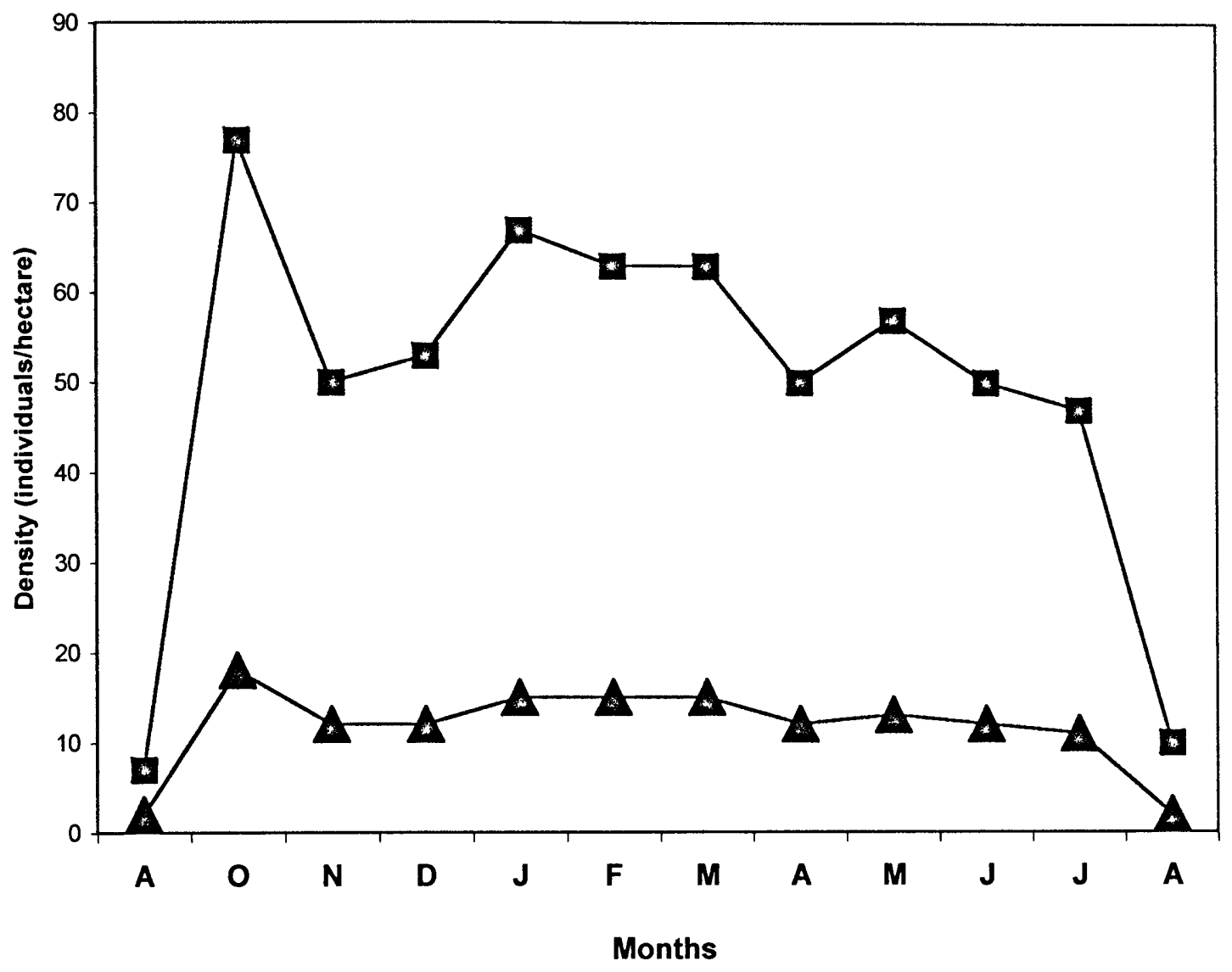

Figure 22. Density per month of Peromyscus gossypinus in hardwood hammock. Dark squares denote biased density estimate. Dark triangles represent corrected density estimate calculated using minimum number alive and Bondrup-Nielsen Boundary strip method (Krebs 1999). 
species. The density of $P$. gossypinus peaked during October at 18 individuals per hectatre and then remained relatively constant at around 12 per hectare until declines in August 1998, and August 1999 dropped the density to two per hectare. The densities of Sigmodon hispidus in Pineland 1 (Figure 23), and Pineland 2 (Figure 24) remained relatively constant throughout the year, with Pineland 2 always having the higher density of S. hispidus of the two pinelands. Summer declines were evident in both pinelands. The density of P. gossypinus in the Schinus location (Figure 25) was much lower than that for individuals of the same species in the hardwood hammocks. A slight increase in the density of $P$. gossypinus occurred in March and April 1999 with noticeable declines again occurring during August 1998 and August 1999. Densities of Rattus rattus showed no discernable trend during the course of the study (Figure 26). Extremely low densities for all species was the norm during the study.

Results of the hierarchical tree cluster analysis (Figure 27) suggest that in terms of capture histories, the two hammocks as one would expect are very similar. The pinelands, and the wetland also display a great degree of similarity, and the monospecific stand of Schinus terebinthifolius has the greatest linkage distance of the seven study sites.

\section{$\underline{\text { Discussion }}$}

This study addressed the lack of baseline data concerning the presence, distribution, population ecology, and habitat and climatic associations of murid rodents in LPK. I captured four species of murid rodents while trapping in the four primary habitat types of LPK. Peromyscus gossypinus is the most abundant species and appears to be a 


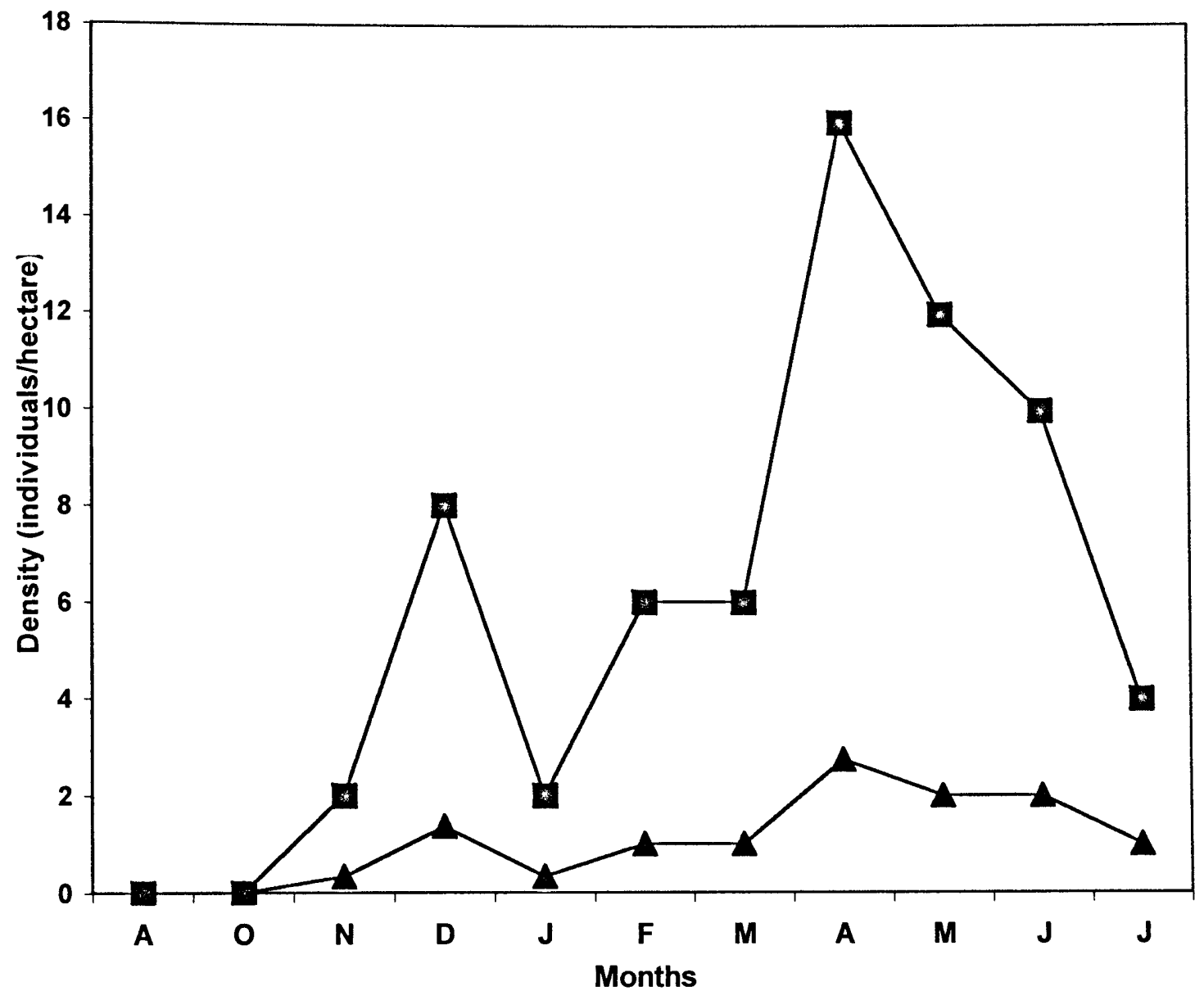

Figure 23. Density per month of Sigmodon hispidus in Redd Pineland (Pineland 1). Dark squares denote biased density estimate. Dark triangles represent corrected density estimate obtained using minimum number alive and BondrupNielsen Boundary Strip method (Krebs 1999). 


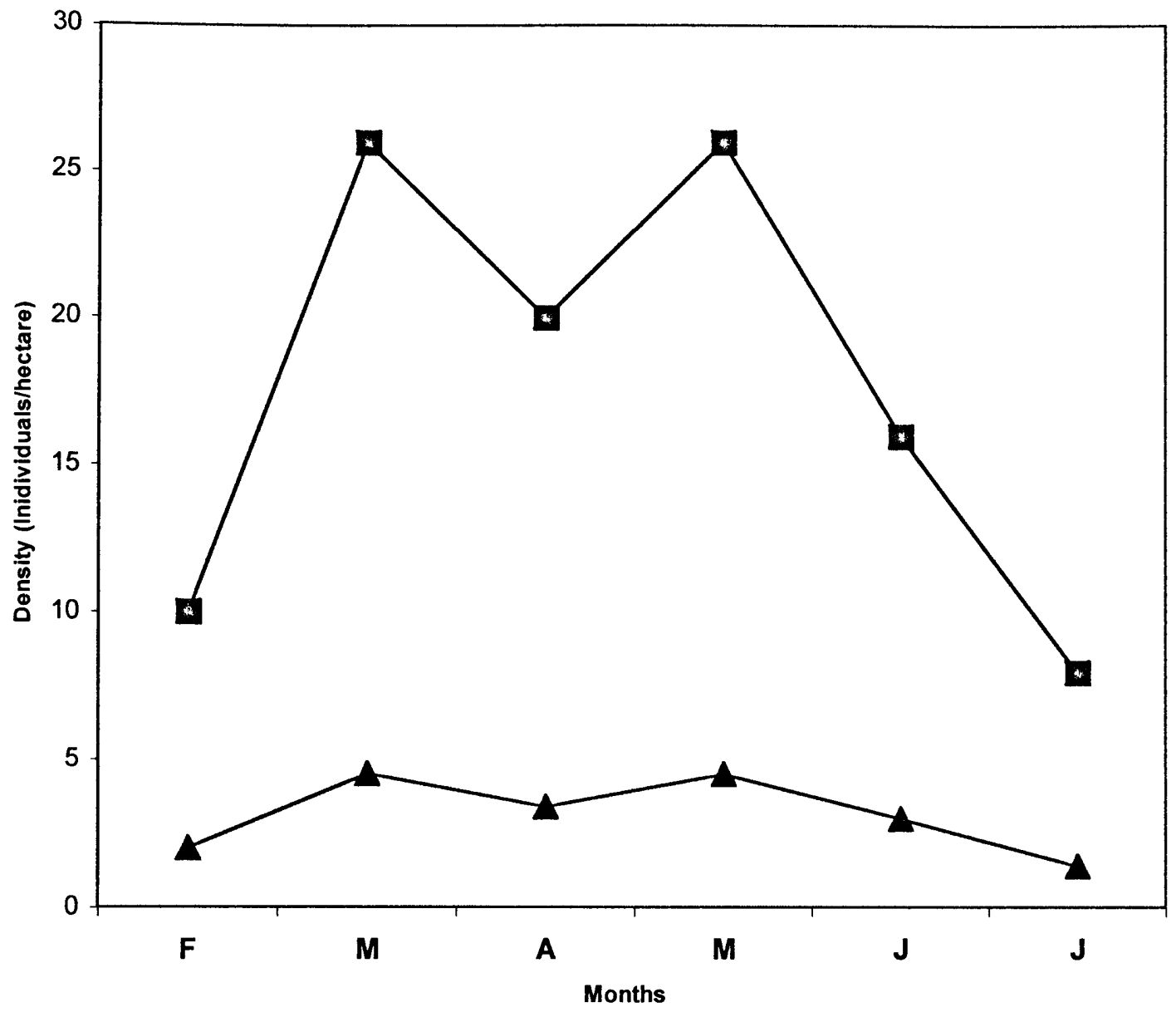

Figure 24. Density per month of Sigmodon hispidus in Grimeshaw Pineland (Pineland 2). Dark squares denote biased density estimate. Dark triangles represent corrected density estimate calculated using minimum number alive and Bondrup-Nielsen Boundary Strip method (Krebs 1999). 


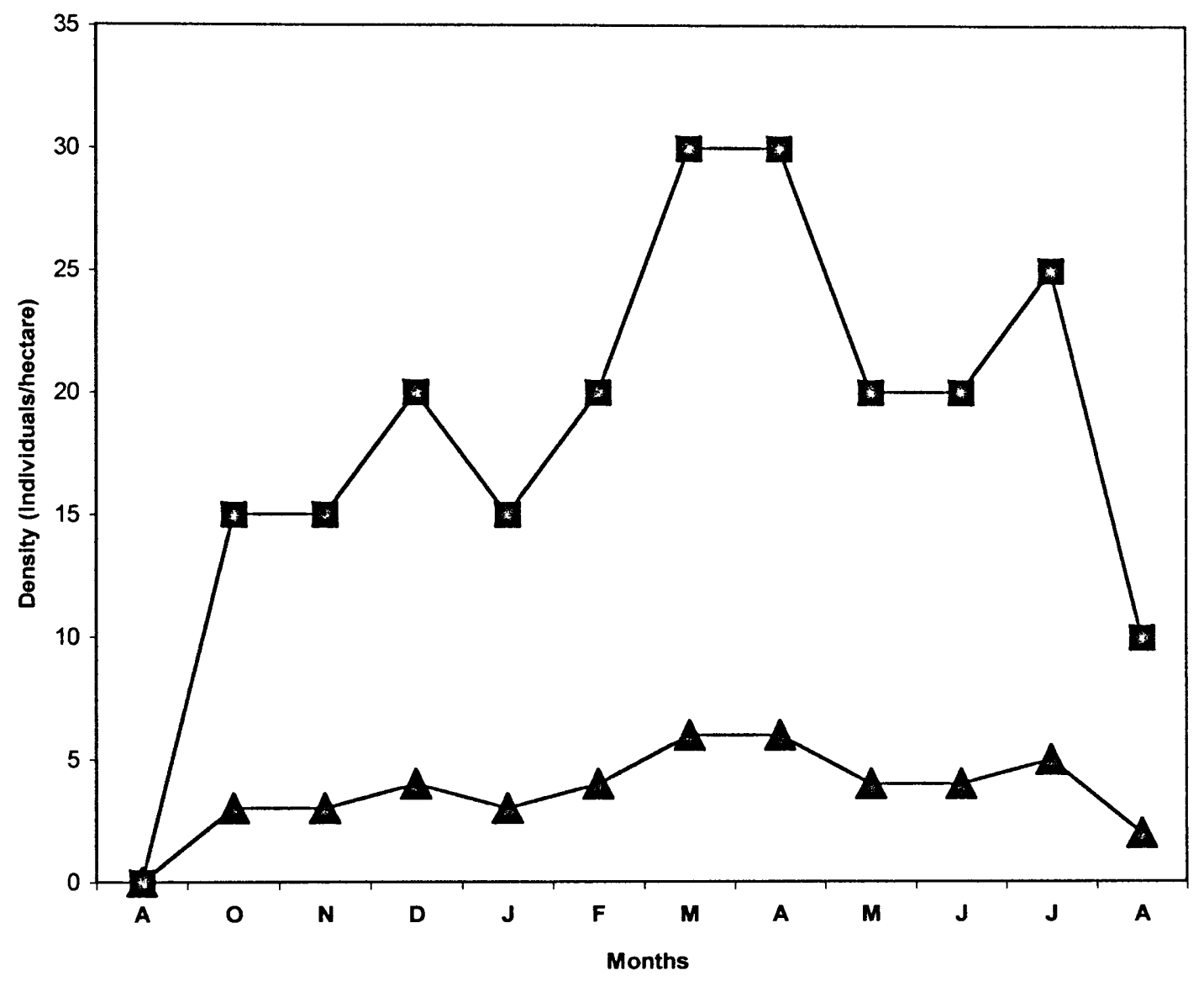

Figure 25. Density per month of Peromyscus gossypinus in Schinus study site. Dark squares denote biased density estimate. Dark triangles represent corrected density estimate calculated using minimum number alive each month, and Bondrup-Nielsen Boundary Strip method (Krebs 1999). 


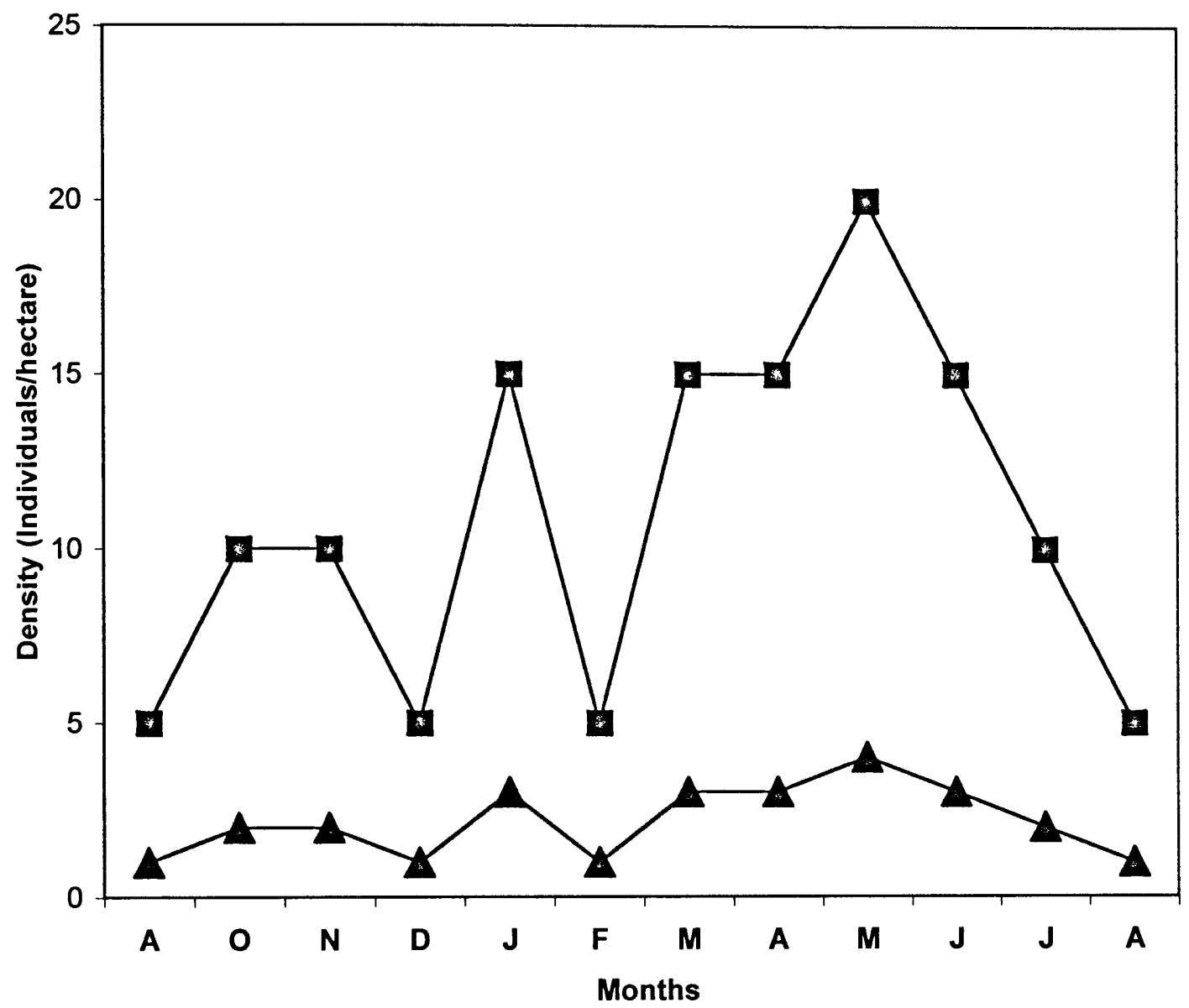

Figure 26. Density per month of Rattus rattus in Schinus study site. Dark squares denote biased density estimate. Dark triangles represent corrected density estimate calculated using minimum number alive and Bondrup-Nielsen Boundary Strip method (Krebs 1999). 


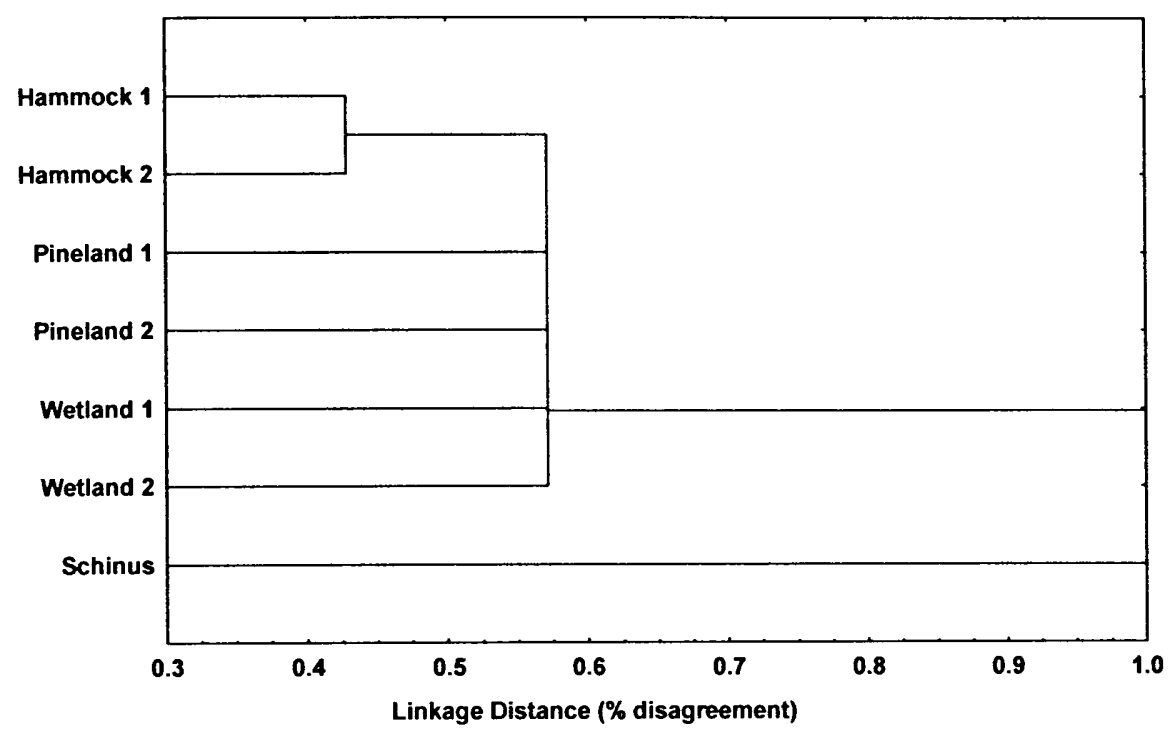

Figure 27. Cluster diagram using mean captures per trap night, proportion of total captures for each species, and number of species captured in each site. 
habitat generalist as I found it in all the trapping sites. While the distribution of $P$. gossypinus is ubiquitous in LPK, it occurs in the highest densities and is the dominant species found in the tropical hardwood hammocks. Sigmodon hispidus was the dominant species found in the pinelands, while $O$. palustris and $R$. rattus were the dominant species in the wetlands and $S$. terebinthifolius areas respectively.

I did not detect a significant effect due to time and found that weather variables were not effective predictors of rodent abundance. Densities and species diversity of murid rodents appear to be low throughout the year in LPK. The lack of an effect on rodent populations due to rainfall be indicate that rodent abundance is also not dependent on fruiting phenology, and other food resource factors often closely related to rainfall.

While my study cannot eliminate peninsular effect as the cause for low species diversity of rodents in south Florida and LPK in particular, it is unlikely that this phenomenon is the cause of the low densities of murid rodents in LPK. Conversely, the low densities appear to suggest that habitat quality for rodents in LPK is poor, and nesting sites, and protection from predators are limiting resources.

\section{Mark-recapture}

While the greatest number of captures occurred in the tropical hardwood hammock, it was also the study location with the lowest species richness. The rodent fauna of hammocks in LPK appears to be dominated by Peromyscus gossypinus, with Sigmodon hispidus occurring in low numbers in the transition zones between young tropical hardwood hammocks, and mature pinelands. Although Redd Hammock was surrounded by the two pineland study locations, there were no instances of movement of 
animals across study sites even though both of the dominant species were found in both habitat types. This would seem to suggest high site fidelity on the part of both species, and that roads and firebreaks in LPK may act as barriers to dispersal for rodents. This finding suggests a top-down mode of regulation for the rodent communities of LPK, indicating that the avoidance of predators plays a crucial role in the distribution and abundance of murid rodents in LPK.

The single $S$. hispidus captured in Redd Hammock was presumed to be a result of the exodus that occurs out of the pine-rocklands during both natural and prescribed burnings. Ironically, all four species of murid rodents present in LPK were also encountered in the Schinus monoculture in the Hole-in-the-Donut area. Although this habitat type exhibited the highest species richness, all species were found in relatively low densities. The introduced, invasive species Rattus rattus was equally abundant as the ubiquitous $P$. gossypinus. Sigmodon hispidus and Oryzomys palustris were both present in negligible numbers. The Hole-in-the-Donut area is surrounded by pine rocklands, most often only separated by a road. It is possible that $S$. hipidus is present only as a transient species, and may use the Brazilian Pepper as a sort of covered walk-way which offers protection from avian predators as individuals migrate between pineland locations.

The rodent fauna of the pinelands in LPK also appears to be dominated by a single species, Sigmodon hispidus. While P. gossypinus was encountered in the pinelands, albeit in low numbers, this cover type appears to be especially suited to the Hispid Cotton Rat. Throughout its North American range the Cotton rat inhabits grassy and weedy fields (Whitaker 1997). The grizzled fur of the cotton rat is predominantly gray with brown or 
sage colored fur interspersed throughout. This coloration is ideally suited for remaining inconspicuous among the hay-like tufts of herbaceous vegetation, and rock substrate of the pinelands of LPK. The coloration may be of particular importance to this species because it remains active during daylight hours. The dense understory layer of herbaceous vegetation present in the pinelands is also well suited to making the characteristic cup shaped nests of woven grass typically associated with this species (Whitaker 1997). While this species most often feeds on green plants, it has been known to take insects, and will readily eat the eggs of quail, which also are predominantly found in the pinelands. The low numbers of $S$. hispidus observed during this study would seem to suggest that the enormous reproductive potential of this species (3-4 litters of up to 15 young each) is being countered by high rates of predation, as it is often the preferred prey of many snakes, birds and other mammals (Gingerich 1996). In areas of sparse vegetation, such as Pineland 1 and the wetlands, the limiting resource for this omnivorous species may not be just food, but a shortage of suitable nest sites as is often the case with species with specialized nesting requirements (Donnelly 1989). Other studies also suggested that the density of Sigmodon was dependent on the density of the herbaceous vegetation of the area (Stoddard 1926). In his studies of rodent communities in Taiwan, Adler (1995) observed that while vertical stratification of the habitat did not increase the species richness or abundance, areas with well developed grass cover and little vertical stratification above the layer of grass had the highest densities of rodents.

As expected the Marsh Rice rat was found predominantly in the wetland sites. This species is a particularly adept swimmer often spending most of its daily active period 
in the water. It can readily dive, and swim underwater. However, it was not found in Wetland 1. This would appear to suggest that the short hydroperiod marshes known as finger-glades, which surround many of the pinelands of LPK are not suitable habitat for this species. The percent cover survey revealed what is evident to the casual observer. The finger glades tend to be much more sparsely vegetated than the longer hydroperiod marshes. Consequently this relatively open habitat affords very little protection from predators, particularly avian predators. The lack of dense vegetation and short hydroperiod may be responsible for the almost complete absence of rodents, and individuals of $O$. palustris in particular. The vegetation survey, and the trapping data in Wetland 2 would appear to support this hypothesis. Wetland 2 has a hydroperiod more akin to those characteristic of true sawgrass prairies like those found in the Taylor Slough area of ENP. The longer hydroperiod in this marsh, along with the increased presence of Cladium jamaicense may offer more resources, and protection from predators. As a result, Wetland 2 was a far more suitable area for Oryzomys palustris.

The explanation for the wide spread distribution of Peromyscus gossypinus may lie in its behavioral ecology, and morphology. Like the non-indigenous Black rat, this species is a particularly adept climber, often climbing up limbs and trunks much like squirrels (Whitaker 1997). The cotton mouse is also a strong swimmer. It is one of only two Florida mice to frequently nest in trees, but nests can also be found in solution holes, under logs, and in between rocky crevices (Gingerich 1996; Whitaker 1997). It is an omnivore which eats everything from seeds and fruits, to invertebrates. The Cotton mouse is also known for great versatility of refuge selection (Frank and Layne 1992). 
These adaptations make this species of rodent particularly versatile and may explain its ubiquitous distribution within LPK. Peromyscus gossypinus is also the smallest and most inconspicuous of all four of the species encountered during trapping, and is exclusively nocturnal. These features, along with its immense reproductive rate may be responsible for this being the most abundant species in LPK. The peaks and valleys in the number of P. gossypinus occurred as expected. Even though this species breeds throughout the year, population sizes and reproductive activity are known to spike during late autumn and early winter, with noticeable declines during summer months (Whitaker 1997). In his study of deer mice (Peromyscus), Fairbairn (1977) concluded that the declines in population size associated with the onset of spring and early summer breeding resulted from the dispersal of light-weight, subordinate males, and high mortality rates among early breeding females. The occurrence of these stochastic events may help to explain the decline in densities of all four species of rodent captured in LPK.

\section{Abiotic Factors}

Despite the highly seasonal rainfall patterns, and distinctive sub-tropical climate of South Florida, none of the weather variables tested appeared to affect rodent populations sizes. The correlations between climatic factors and captures per trap night per month yielded no significant associations. Climatological variables also appear to be poor predictors of rodent population sizes in LPK, as evidenced by the results of the multiple regression. This suggests that other factors such as patterns of plant reproductive phenology, hydrology, predator cycles, food availability, and disturbances such as fires and hurricanes may be more effective predictors of the population size of rodents. The lack of 
a statistically significant effect in the ANOVA due to temporal variation may be due to the lack of association between climatic variables and population sizes. The high degree of variation in climatic variables such as rainfall, temperature and humidity was not mirrored by the number of captures per month, although oscillations in number of captures did occur. It is possible that rodents of LPK may have unknown species specific requirements that affect their population dynamics at any given time. The abundance of a particular seed or fruit, or plant used as nesting material may be enough to trigger spikes in population size which level off as the abundance of the particular resource dwindles. Other studies have found that patch size (Foster and Gaines 1991), and the density of vegetation (Stoddard 1926; Adler 1995) are often sufficient to explain variations in animal density. Habitat loss maybe particularly important in highly seasonal and successional communities such as LPK.

\section{Sampling effort}

The species accumulation curve shows that sampling effort during the course of the study was more than adequate in its intensity. It is highly unlikely that another species of murid rodent occurs in LPK and went undetected during the course of the study. The species accumulation curve reached an asymptote after few individuals were captured. There is no reason to believe that if sampling time were extended, more species would be encountered. The mark-recapture histories outlined in the Method B tables also lend credence to the fact that sampling effort was sufficiently intensive and adequate in its scope. Since most marked individuals were caught in the previous sampling occasion, one can only conclude that the capture program was sufficiently intensive to sample the 
population, or that the population is very small. Either scenario shows that the 4,809 total trap nights were enough to adequately and effectively sample the areas. While other studies have reported that adult Sigmodon inhibit the trappability of younger individuals (Summerlin and Wolfe 1973; Joule and Cameron 1974), the large proportion of captured juveniles of Sigmodon hispidus in my study suggests that the trapping array and design was not biased in this regard.

With the effectiveness of the trapping regime one can only conclude that rodent diversity (richness and evenness) is very low in the LPK area of ENP. The lack of high murid rodent biodiversity may be due to factors such as peninsular effect, low productivity, poor habitat quality, or a combination of all three. The trend towards decreased biodiversity as one proceeds south through peninsular Florida is particularly evident in the rodent family Muridae. Of the 16 species of murid rodents found in the state of Florida, only half are present south of Lake Okeechobee. Long Pine Key appears to be particularly depauperate with only three indigenous murid species. Other studies have found it difficult to prove that reduction in species diversity in a given area is due to a significant peninsular effect (Barbosa and Benzal 1996). It seems that species in southern Florida face three factors that might reduce species density. The geographic location at the southern tip of a peninsula may have immigration and colonization effects similar to those of distant islands. Second, South Florida pinelands, the dominant habitat type in Long Pine Key are known to be oligotrophic, and hence fall on the short end of the productivity/diversity relationship which, according to Rosenzweig (1992), would favor intermediate levels of productivity to have higher levels of biodiversity. The extremely 
low numbers of rodents encountered would suggest that the available habitat is of poor quality. Busack and Hedges (1984) reached similar conclusions in their study of peninsular effect on the herpetofauna of Florida, noting that there was no significant peninsular effect, and that the general trend towards reduced species diversity down the latitudinal gradient was most likely due to a reduction in habitat quality (Dalrymple 1988). It is difficult to discount any of the three factors when characterizing the LPK rodent fauna as depauperate.

The densities of the 4 species I encountered were much lower than previous estimates obtained in a study of the tree islands of Everglades National Park (Smith and Vrieze 1979). While there was a huge discrepancy between the two studies, my results for Peromyscus gossypinus are higher than those reported in other studies in East Texas (McCarley 1954 and 1959), and Northern Florida (Layne 1974). The densities I obtained for Sigmodon are on the lower end of density range from nine studies reviewed by Layne (1974). The density of Oryzomys palustris was considerably lower in my study than those reported in Negus et al. (1961). The low densities exhibited by all four species maybe the result of using a conservative measure of population size such as the minimum number alive, to estimate densities. Also differences in methodologies make it difficult to compare densities across studies. While sampling and mathematical methodologies may contribute to the low density of animals, it remains difficult to discount factors such as predation pressure, habitat quality, food availability, and patch size. Also, it is worth noting my sampling regime took place during a La Niña year. This may have affected the 
distribution and abundance of the rodents, and also altered relationships with climatic variables.

\section{Estimation of Population Size}

As a consequence of the length of this study, simple population estimators such as the Lincoln-Petersen method and the Schnabel method could not be used (Krebs 1999). The yearlong trapping regime of this study violated the assumptions of no births, deaths, immigrations, or emigrations required by simple estimators. These assumptions could not be met biologically, as a consequence of the short life spans ( $<$ one year in the wild) of the individuals captured. As a result, I chose a more realistic population estimator such as the Jolly-Seber method of population estimation to analyze the results of the mark-recapture portion of the study. Using this open population estimator, the crucial assumption became random sampling, with at least batch specific markings also being essential. While the Jolly-Seber population estimation method is the most effective and widely used open population estimator (Sutherland 1996; Krebs 1999), it yielded highly questionable results herein. The most realistic estimates of population size I obtained were for the data gathered in the tropical hardwood hammock, where the sample was largest. In all other instances, the estimator oscillated wildly from periods of extinctions to unrealistic estimates, often lower than those obtained using the minimum number alive. Probabilities of survival also decreased in accuracy and biological significance as the number of animals captured approached zero. In fact, all Jolly-Seber estimates are very imprecise unless the number of marked animals in each sample is greater than 10 (Sutherland 1996). Due to the low number of captures and apparent depauperate nature of the rodent fauna of LPK, 
this stipulation was virtually out of reach in all instances. The low number of total captures, and the even smaller number of recaptures in each sampling period made it impossible to test the assumption of homogeneity of capture probabilities of individuals, another critical assumption of the Jolly-Seber model. As a frame of reference and standard of comparison, the minimum number alive at any given time $t$ was also obtained. Naturally this estimate will always be within biologically realistic and significant bounds, but will invariably underestimate the true population size. The results of the Method B tables lend credence to the fact that population sizes in the study areas are small. In an intensive mark-recapture program, most of the marked animals caught will have been last caught at the previous sampling (Krebs 1999), and will as a result appear along the subdiagonal of the Method B table as is the case in this study. When sampled populations are very large, or the sampling is less intensive, recaptures will increasingly appear above the subdiagonal of the Method B table, due to the fact that marked individuals will typically evade capture for several sampling periods.

\section{Conclusion}

At a time when declines in biodiversity, and their associated causes and community and landscape level effects are at the forefront of ecological investigations, it is becoming increasingly important to obtain adequate baseline data concerning population dynamics, ecology, distribution and behavior. This is particularly true for taxa whose presence or absence can lead to widespread changes, and affect the structure and function of 
ecological communities and systems. Rodents play essential roles in the trophic dynamics of many complex systems and are essential components of many biological communities.

This investigation provided a comprehensive study of the murid rodent fauna of Long Pine Key. The LPK region of Everglades national park appears to be depauperate in terms of its rodent fauna, with far fewer species present than normally encountered in the typical xeric pinelands of northern Florida (Stout et al. 1988). With only three native species present, a combination of factors such as peninsular effect, low productivity, and poor habitat quality may be responsible for the low species richness and the apparently low densities of rodents present.

It appears that the avoidance of predators may be the single most important factor determining the presence and abundance of rodents in a particular habitat type and location. As a result, areas with open canopies and sparse vegetation were essentially barren and devoid of rodents. Frequent burnings of pinelands and short hydroperiod finger-glades may result in sparse vegetation with low levels of percent cover and a shortage of tall woody vegetation. Consequently this leads to an overall decrease in rodents when compared to similar locations with more highly developed understory vegetation, and more instances of tall woody vegetation. Due to the important nature of the roles played by small mammals in biological communities, further studies into the effects of fire on animal communities is needed. Studies of the predation pressure exerted on small mammals by both terrestrial and avian predators, as well as studies documenting predator abundance would also be helpful in understanding the population dynamics of their preferred prey, rodents. Limiting the growth of understory plants in pinelands with 
frequent prescribed burnings may have a significant impact on the rodent populations of LPK, and the populations of their numerous associated predators. A greater amount of interspersion and heterogeneity of habitat types, and an increase in the size of tropical hardwood hammocks in LPK may result in an increased abundance of small mammals in LPK, and an improvement in habitat quality for other taxa of vertebrates. 


\section{$\underline{\text { Literature Cited }}$}

Abramsky, Z., and M.L. Rosenzweig. 1984. Tilman's predicted productivity-diversity relationships shown by desert rodents. Nature 309:1 50-151.

Adler, G.H. 1994. Tropical forest fragmentation and isolation promote ansynchrony among populations of a frugivorous rodent. J. of Animal Ecology 63: 903-911.

Adler, G.H. 1995. Habitat relations within lowland grassland rodent communities in Taiwan. Journal of Zoology 237: 563-576.

Adler, G.H., and R. Levins. 1994. The island syndrome in rodent populations. Quarterly Review of Biology 69:473-490.

Adler, G.H., and R.P. Beatty. 1997. Changing reproductive rates in a Neotropical forest rodent, Proechimys semispinosus. J. of Animal Ecology 66: 472-480.

Anderson, P.K. 1989. Dispersal in rodents: a resident fitness hypothesis. American Society of Mammalogists, Special Publication Number 9.

Barbosa, A., and J. Benzal. 1996. Diversity and abundance of small mammals in Iberia: Peninsular effect of habitat suitability? International Journal of Mammalian Biology 61: 236-241.

Boitani, L., and S. Bartoli. 1983. Simon and Schuster's Guide to: Mammals. Simon and Schuster Publishing, New York, NY.

Bondrup-Nielsen, S. 1983. Density estimation as a function of live trapping grid and home range size. Canadian Journal of Zoology 61: 2361-2365.

Bowers, M.A., and C.A. Flanagan. 1988. Microhabitat as a template for the organization of a desert rodent community In Management of Amphibians, Reptiles, and Small Mammals in North America. R.C. Szaro, K.E. Severson, and D.R. Patton (eds.) U.S.D.A. Forest Service General Technical Report RM-166.

Burt, W.E., and R.P. Grossenheider. 1980. Peterson Field Guides: A Field Guide to the Mammals. Houghton Mifflin Company, New York, NY.

Busack, S.D., and S.B. Hedges. 1984. Is the peninsular effect a red herring? American Naturalist 123:266-275.

Craighead, F.C., Sr. 1961. Brief report on activities pertaining to plant studies in the Everglades National Park during 1960-61. Unpubl. report on file in the Everglades National Park Reference Library. 
Crump, M.L. 1996. Keys to a successful project: Associated data and planning In Measuring and Monitoring Biological Diversity. Standard Methods for Mammals. D.E Wilson, F.R. Cole, J.D. Nichols, R. Rasanayagam, and M.S. Foster. Smithsonian Institution Press, Washington, D.C.

Currie, D.J., and V. Paquin. 1987. Large-scale biogeographical patterns of species richness of trees. Nature 329:326-327.

Dalrymple, G.H. 1988. The herpetofauna of Long Pine Key, Everglades National Park, in relation to vegetation and hydrology In Management of amphibians, reptiles, and small mammals in North America. R.C. Szaro, K.E. Severson, and D.R. Patton (eds.) pages 72-86. U.S.D.A. Forest Service. General Technical Report RM-166.

Dalrymple, G.H., T.M. Steiner, R.J. Nodell, and F.S. Bernardino Jr. 1991. Seasonal activity of the snakes of Long Pine Key, Everglades National Park. Copeia 2:294-302.

Davis, J.H. 1943. The natural features of southern Florida. Geological Bulletin 25, Florida Geological Society.

Donnelly, M.A. 1989. Demographic effects of reproductive resource supplementation in a territorial frog, Dendrobates pumilio. Ecological Monographs 59: 207-221.

Doren, R.F., D.L. Childers, T.V. Armentano, W.J. Platt, C. Horvitz, M. Norland, and B. Sparkman. 1997. Restoring wetlands on abandoned agricultural lands in Everglades National Park: A strategic plan for guiding research, monitoring, and management of the "Hole-in-the-Donut" restoration program. South Florida Natural Resources Center Report 97-002. 35 p.

Dunaway, P.B., and S.V. Kaye. 1964. Weights of cotton rats in relation to season, breeding, and environmental radioactive contamination. Amer. Midland Nat. 71:141-155.

Elkinton, J.S., W.M. Healy, J.P. Buonaccorsi, G.H. Boettner, A.M. Hazzard, H.R. Smith, and A.M. Leibhold. 1996. Interactions among gypsy moths, white-footed mice, and acorns. Ecology 77: 2332-2342.

Fairbairn, D.J. 1977. The spring decline in deer mice: death or dispersal? Canadian Journal of Zoology 55: 84-92.

Fleming, T.H. 1971. Population ecology of three species of neotropical rodents. Miscellaneous Publication of the Museum of Zoology, University of Michigan, 143:1-77. 
Fleming, T.H. 1975. The role of small mammals in tropical ecosystems In Small mammals their productivity and population dynamics. F.B. Golley, K. Petrusewicz, and L. Ryszkowski (eds.) pages 269-298. Cambridge University Press, Cambridge, United Kingdom.

Fleming, T.H. 1979. Do tropical frugivores compete for food? American Zoologist 19:1157-1172.

Foster, R.B. 1982. The seasonal rhythm of fruit fall on Barro Colorado Island In The Ecology of a Tropical Forest. Seasonal Rhythms and Long-term Changes. E.G. Leigh Jr., A.S. Rand, and D.M. Windsor (eds.) pages 151-172. Smithsonian Institution Press, Washington, D.C.

Foster, J. and M.S. Gaines. 1991. The effects of a successional habitat mosaic on a small mammal community. Ecology 72: 1358-1373.

Frank, P.A. and J.N. Layne. 1992. Nests and daytime refugia of Cotton mice (Peromyscus gossypinus) and Golden Mice (Ochrotomys nuttalli) in Southcental Florida. American Midland Naturalist 127: 21-30.

Gentry, C.R. 1984. Hurricanes in south Florida In Environments of South Florida: Present and Past II. P.J. Gleason (editor). Memoir II, Miami Geological Society, Miami, FL.

Gingerich, J.L. 1996. Florida's Fabulous Mammals. World Publications. Tampa, FL.

Hanski, I., L. Hansson, and H. Henttonen. 1991. Specialist predators, generalist predators, and the microtine rodent cycle. J. Anim. Ecol. 60:353-367

Hanski, I., P. Turchin, E. Korpimaki, and H. Henttonen. 1993. Population oscillations of boreal rodents: regulation by mustelid predators leads to chaos. Nature 364:232235.

Ims, R.A., and H. Steen. 1990. Regional synchrony of cyclic microtine populations: A theoretical evaluation of the role of nomadic predators. Oikos 57: 381-387.

Jolly, G.M. 1965. Explicit estimates from capture-recapture data with both death and immigration-stochastic model. Biometrika 52: 225-247.

Jones, C., W.J. McShea, M.J. Conroy, and T.H. Kunz. 1996. Capturing Mammals In Measuring and Monitoring Biological Diversity: Standard Methods for Mammals. D.E. Wilson, F.R. Cole, J.D. Nichols, R. Rundran, and M.S. Foster (eds.). Smithsonian Institution Press, Washington, D.C. 
Joule, J., and G.N. Cameron. 1974. Field estimation of demographic parameters: influence on Sigmodon hispidus population structure. Journal of Mammalogy 55: 309-318.

Kirchner, T.B. 1977. The effects of resources enrichment on the diversity of plants and arthropods in a short grass prairie. Ecology 58: 1334-1344.

Korpimaki, E., and K. Norrdahl. 1998. Experimental reduction of predators reverses the crash phase of small-rodent cycles. Ecology 79: 2448-2455.

Krebs, C.J. 1966. Demographic changes in fluctuating populations of Microtus californicus. Ecological Monographs 36: 239-273.

Krebs, C.J. 1999. Ecological Methodology $2^{\text {nd }}$ ed. Addison Wesley Educational Publishing, Menlo Park, CA.

Lawlor, T.E. 1983. The peninsular effect on mammalian species diversity in Baja California. American Naturalist 121:432-439.

Layne, J.N. 1974. Ecology of small mammals in a flatwoods habitat in north-central Florida, with emphasis on the cotton rat (Sigmodon hispidus). Amer. Mus. Novitates 2544: 1-48.

Leslie, P.H., and Chitty, D. 1951. The estimation of population parameters from data obtained by means of the capture-recapture method. I. The maximum likelihood equations for estimating the death-rate. Biometrika 38: 269-292.

Lodge, T.E. 1994. The Everglades Handbook: Understanding the Ecosystem. St. Lucie Press, Delray Beach, FL. 227 p.

Loope, L.L. 1992. An overview of problems with introduced plant species in national parks and biosphere reserves of the United States In Alien plant invasions in native ecosystems of Hawaii: Management and research. D.P. Stone, D.W. Smith, and J.T. Tunison (eds.) University of Hawaii Cooperative National Park Resources Study Unit, Honolulu, Hawaii.

Loope, L.L., and N.H. Urban. 1980. A survey of fire history and impact in tropical hardwood hammocks in the east Everglades and adjacent portions of Everglades National Park. South Florida Research Center Report T-592. Everglades National Park, Homestead, FL. 9 p. 
Loope, L.L., and V.L. Dunevitz. 1981. Impact of fire exclusion and invasion of Schinus terebinthifolius on limestone rockland pine forests of southeastern Florida. South Florida Research Center Report T-645. Everglades National Park, Homested, Fl. $30 \mathrm{p}$.

Loope, L.L., D.W. Black, S. Black, and G.N. Avery. 1979. Distribution and abundance of flora in limestone rockland pine forests of southeastern Florida. South Florida Research Center Report T-547. Everglades National Park, Homestead, FL. 37 p.

Mabberley, D. J. 1987. The Plant Book. Cambridge University Press, Cambridge, UK. pp. 706.

MacArthur, R.H., and E.O. Wilson. 1967. The Theory of Island Biogoegraphy. Princeton University Press, Princeton, N.J.

Macdonald, D.W. 1995. The Encyclopedia of Mammals. Facts on File, Inc. New York, NY.

Mares, G.G., and K. Ernest. 1995. Population and community ecology of small mammals in a gallery forest of central Brazil. J. of Mammalogy 76:750-767.

McCarley, W.H. 1954. Fluctuations and structure of Peromyscus gossypinus populations in eastern Texas. Journal of Mammalogy 35: 526-532.

McCarley, W.H. 1959. A study of the dynamics of a population of Peromyscus gossypinus and $P$. nuttalli subjected to the effects of X-irradiation. American Midland Naturalist 61: 447-469.

Musser, G.G., and M.D. Carleton. 1993. Family Muridae In Mammal Species of the World: A Taxonomic and Geographic Reference. D.E Wilson, and D.M. Reeder (eds.) pages 73-93. Smithsonian Institution Press, Washington, D.C.

Negus, N.C., E. Gould, and R.K. Chipman. 1961. Ecology of the rice rat, Oryzomys palustris (Harlan), on Breton Island, Gulf of Mexico, with a critique of the social stress theory. Tulane Studies Zool., 8: 93-123.

Nichols, J.D., and Conroy, M.J. 1996. Techniques for estimating abundance and species richness In Measuring and Monitoring Biological Diversity. Standard Methods for Mammals. D.E. Wilson, F.R. Cole, J.D. Nichols, R. Rasanayagam, and M.S. Foster. Smithsonian Institution Press, Washington, D.C. 
Olmstead, I.C., L.L. Loope, and C.E. Hilsenbeck. 1980. Tropical hardwood hammocks of the interior of Everglades National Park and Big Cypress National Preserve. South Florida Research Center Report T-604. Everglades National Park, Homestead, FL. 58 p.

Olmstead, I.C., W.B. Robertson Jr., J. Johnson, and O.L. Bass Jr. 1983. The vegetation of Long Pine Key, Everglades National Park. South Florida Research Center Report SFRC-83/05. Everglades National Park, Homestead, FL. 64 p.

Ostfeld, R.S., C.G. Jones, and J.O. Wolff. 1996. Of mice and mast. Bioscience 46: 323-330.

Owen, J.G. 1988. On productivity as a predictor of rodent and carnivore diversity. Ecology 69:1161-1165.

Pianka, E.R. 1967. On lizard species diversity: North American flatlands deserts. Ecology 48: 333-351.

Rexstad, E. 1994. Detecting differences in wildlife populations across time and space. Proceedings from $59^{\text {th }}$ North American natural resource and wildlife conference pages 219-228.

Robertson, W.B. 1953. A survey of the effects of fire in Everglades National Park. Mimeo. Rept. 169 p.

Robertson, W.B. 1955. An analysis of the breeding-bird populations of tropical Florida in relation to the vegetation. Ph.D. Thesis, Univ. of Illinois. 599 p.

Rosenzweig, M.L. 1992. Species diveristy gradients: We know more and less than we thought. J. of Mammalogy 73:715-730.

Shmida, A., M. Evenari, and I. Noy-Meir. 1986. Hot desert ecosystems: an integrated view In Ecosystems of the World. Vol. 12B. Hot deserts and shrublands.

M. Evenari, I. Noy-Meir, and D.W. Goodall (eds.) pages 379-387. Elsevier Science Publishers, Amsterdam.

Silvertown, J. 1980. The dynamics of a grassland ecosystem: botanical equilibrium in the park grass experiment. Journal of Applied Ecology 17:491-504.

Simpson, G.G. 1964. Species densities of North American recent mammals. Systematic Zoology 13:57-73.

Smith, A. T., and J.M. Vrieze. 1979. Population structure of Everglades rodents: Responses to a patchy environment. Journal of Mammalogy 60: 778-794. 
Snyder, J.R. 1986. The impact of wet season and dry season prescribed fires on Miami Rock Ridge pineland, Everglades National Park. National Park Service, South Florida Research Center Report SFRC-86/06. Everglades National Park, Homestead, FL. 30 p.

SPSS Graduate Pack (for Windows). Version 8.01. SPSS, Inc. Chicago, IL.

Statistica (for Windows). Version 5.1. 1997. Statsoft, Inc. Tulsa, OK.

Summerlin, C.T., and J.L. Wolfe. 1973. Social influences on trap response of the cotton rat, Sigmodon hispidus. Ecology 54: 1156-1159.

Sutherland, W.J. 1996. Ecological Census Techniques: A Handbook, pp. 336. Cambridge University Press, Cambridge.

Stoddard, H.L. 1926. Report on Co-operative Quail Investigation: 1925-1926 Cited In A. Leopold. 1933. Game Management. University of Wisconsin Press pp. 481.

Taylor, R.J., and P.J. Regal. 1987. The peninsular effect on species diversity and the biogeography of Baja California. American Naturalist 112:583-593.

Tilman, D. 1982. Resource Competition and Community Structure. Princeton University Press, Princeton, New Jeresy, 296 pp.

Trostel, K., A.R.E. Sinclair, C.J. Walters, and C.J. Krebs. 1987. Can predation cause the 10-year hare cycle? Oecologia 74:185-192.

Whitaker, J. Jr. 1997. The Audubon Society: Field Guide to North American Mammals $2^{\text {nd }}$ edition. Alfred A. Knopf Publisher, New York, NY.

Whiteaker, L.D., and R.F. Doren. 1989. Exotic plant management strategies and list of exotic species in prioritized categories for Everglades National Park. U.S. Department of the Interior, National Park Service, Research/Resource Management Technical Report SER-80/04. Southeast regional office, Atlanta, GA. 21 p. (Electronic copy on the World Wide Web; URL [http://everglades.fiu.edu/]. Florida International University, Miami, FL.

Wilson, D.E., and D.M. Reeder. 1993. Mammal Species of the World: A Taxonomic and Geographic Reference $2^{\text {nd }}$ edition. Smithsonian Institution Press, Washington, D.C. 
Wilson, D.E., F.R. Cole, J.D. Nichols, R. Rundran, and M.S. Foster. 1996. Measuring and Monitoring Biological Diversity. Standard Methods for Mammals.

Smithsonian Institution Press, Washington, D.C. 
Appendix 1A. Method B (Krebs 1999) table for Peromyscus gossypinus in Redd Hammock used to calculate Jolly-Seber estimate of population size.

\begin{tabular}{|c|c|c|c|c|c|c|c|c|c|c|c|c|}
\hline \multirow{2}{*}{$\begin{array}{l}\text { Time of Last } \\
\text { Capture }\end{array}$} & \multicolumn{12}{|c|}{ Time of Capture } \\
\hline & 1 & 2 & 3 & 4 & 5 & 6 & 7 & 8 & 9 & 10 & 11 & 12 \\
\hline 1 & & & 0 & 0 & 0 & 0 & 0 & 0 & 0 & 0 & 0 & 0 \\
\hline 2 & & & 5 & 0 & 1 & 0 & 0 & 0 & 0 & 0 & 0 & 0 \\
\hline 3 & & & & 7 & 0 & 2 & 0 & 0 & 0 & 0 & 0 & 0 \\
\hline 4 & & & & & 7 & 0 & 0 & 0 & 0 & 0 & 0 & 0 \\
\hline 5 & & & & & & 11 & 1 & 0 & 0 & 0 & 0 & 0 \\
\hline 6 & & & & & & & 11 & 1 & 0 & 1 & 0 & 0 \\
\hline 7 & & & & & & & & 9 & 2 & 0 & 0 & 0 \\
\hline 8 & & & & & & & & & 7 & 1 & 0 & 0 \\
\hline 9 & & & & & & & & & & 8 & 1 & 0 \\
\hline 10 & & & & & & & & & & & 7 & 0 \\
\hline 11 & & & & & & & & & & & & 2 \\
\hline T. marked & 0 & 0 & 5 & 7 & 8 & 13 & 12 & 10 & 9 & 10 & 9 & 2 \\
\hline T. unmark. & 2 & 23 & 10 & 7 & 9 & 4 & 4 & 1 & 5 & 3 & 5 & 1 \\
\hline T. caught & 2 & 23 & 15 & 14 & 17 & 17 & 16 & 11 & 14 & 13 & 14 & 3 \\
\hline T. released & 2 & 23 & 15 & 14 & 17 & 17 & 15 & 11 & 14 & 13 & 14 & 3 \\
\hline
\end{tabular}


Appendix 1B. Method B table (Krebs 1999) for Sigmodon hispidus in Pineland 1, used to calculate Jolly-Seber estimates of population size. Total marked $(\mathrm{m})$, total unmarked (u), total caught (n), total released (s), number of individuals released and caught again at a later sample (R), number of individuals marked before sample $t$, not caught in sample $t$, but caught in some sample after sample $t(Z)$.

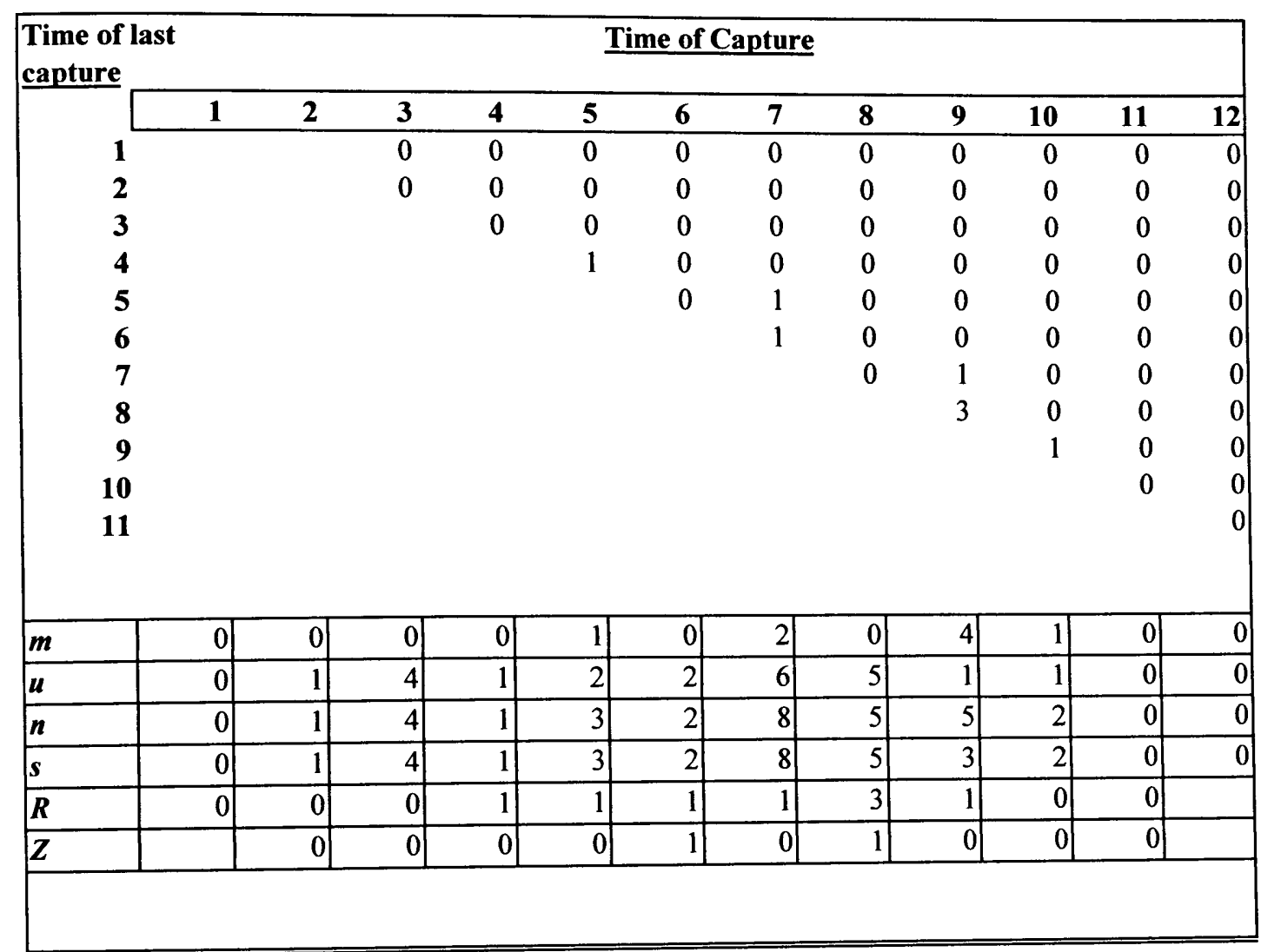


Appendix 1C. Method B table (Krebs 1999) for Sigmodon hispidus in Pineland 2, used to calculate Jolly-Seber estimates of population size. Total marked (m), total unmarked (u), total caught $(n)$, total released (s), number of individuals released and caught again at a later sample (R), number of individuals marked before sample $t$, not caught in sample $t$, but caught in some sample after sample $t(Z)$.

\begin{tabular}{|c|c|c|c|c|c|c|c|}
\hline \multirow{8}{*}{$\begin{array}{l}\text { Time of } \\
\text { last } \\
\text { capture }\end{array}$} & \multicolumn{7}{|c|}{$\begin{array}{l}\text { Time of } \\
\text { Capture }\end{array}$} \\
\hline & 1 & 2 & 3 & 4 & 5 & 6 & 7 \\
\hline & 1 & 3 & 0 & 0 & 0 & 0 & 0 \\
\hline & 2 & & 3 & 1 & 0 & 0 & 0 \\
\hline & 3 & & & 3 & 0 & 0 & 0 \\
\hline & 4 & & & & 4 & 0 & 0 \\
\hline & 5 & & & & & 0 & 0 \\
\hline & 6 & & & & & & 0 \\
\hline$m$ & 0 & 3 & 3 & 4 & 4 & 0 & 0 \\
\hline $\boldsymbol{u}$ & 5 & 10 & 6 & 9 & 3 & 4 & 0 \\
\hline \begin{tabular}{|l|}
$n$ \\
\end{tabular} & 5 & 13 & 9 & 13 & 7 & 4 & 0 \\
\hline $\boldsymbol{s}$ & 5 & 12 & 9 & 12 & 7 & 4 & 0 \\
\hline$R$ & 3 & 4 & 3 & 4 & 0 & 0 & \\
\hline$Z$ & & 0 & 1 & 4 & 0 & 0 & \\
\hline
\end{tabular}


Appendix 1D. Method B table (Krebs 1999) for Peromyscus gossypinus in the Hole-inthe-Donut, used to calculate Jolly-Seber estimates of population size. Total marked (m), total unmarked $(\mathrm{u})$, total caught $(\mathrm{n})$, total released $(\mathrm{s})$, number of individuals released and caught again at a later sample (R), number of individuals marked before sample t, not caught in sample $t$, but caught in some sample after sample $t(Z)$.

\begin{tabular}{|c|c|c|c|c|c|c|c|c|c|c|c|c|}
\hline \multirow{2}{*}{$\begin{array}{l}\text { Time of last } \\
\text { capture }\end{array}$} & \multicolumn{12}{|c|}{ Time of Capture } \\
\hline & 1 & 2 & 3 & 4 & 5 & 6 & 7 & 8 & 9 & 10 & 11 & 12 \\
\hline 1 & & 0 & 0 & 0 & 0 & 0 & 0 & 0 & 0 & 0 & 0 & 0 \\
\hline 2 & & & 2 & 0 & 0 & 0 & 0 & 0 & 0 & 0 & 0 & 0 \\
\hline 3 & & & & 1 & 0 & 0 & 0 & 0 & 0 & 0 & 0 & 0 \\
\hline 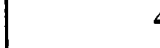 & & & & & 0 & 0 & 2 & 0 & 0 & 0 & 0 & 0 \\
\hline 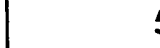 & & & & & & 0 & 0 & 0 & 1 & 0 & 0 & 0 \\
\hline ran & & & & & & & 1 & 0 & 0 & 0 & 0 & 0 \\
\hline & & & & & & & & 3 & 0 & 0 & 0 & 0 \\
\hline 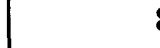 & & & & & & & & & 2 & 1 & 0 & 0 \\
\hline 9 & & & & & & & & & & 1 & 1 & 0 \\
\hline 10 & & & & & & & & & & & 3 & 0 \\
\hline 11 & & & & & & & & & & & & 2 \\
\hline 12 & & & & & & & & & & & & \\
\hline$m$ & 0 & 0 & 2 & 1 & 0 & 0 & 3 & 3 & 3 & 2 & 4 & 2 \\
\hline$u$ & 0 & 3 & 1 & 3 & 1 & 1 & 2 & 2 & 0 & 1 & 1 & 0 \\
\hline$n$ & 0 & 3 & 3 & 4 & 1 & 1 & 5 & 5 & 3 & 3 & 5 & 2 \\
\hline $\boldsymbol{s}$ & 0 & 3 & 3 & 3 & 1 & 1 & 5 & 5 & 3 & 3 & 5 & 2 \\
\hline$R$ & 0 & 2 & 1 & 2 & 1 & 1 & 3 & 3 & 2 & 3 & 2 & \\
\hline$Z$ & & 0 & 0 & 0 & 2 & 3 & 1 & 1 & 1 & 1 & 0 & \\
\hline
\end{tabular}


Appendix 1E. Method B table (Krebs 1999) for Rattus rattus in the Hole-in-the-Donut, used to calculate Jolly-Seber estimates of population size. Total marked (m), total unmarked (u), total caught (n), total released (s), number of individuals released and caught again at a later sample (R), number of individuals marked before sample $t$, not caught in sample $t$, but caught in some sample after sample $t(Z)$.

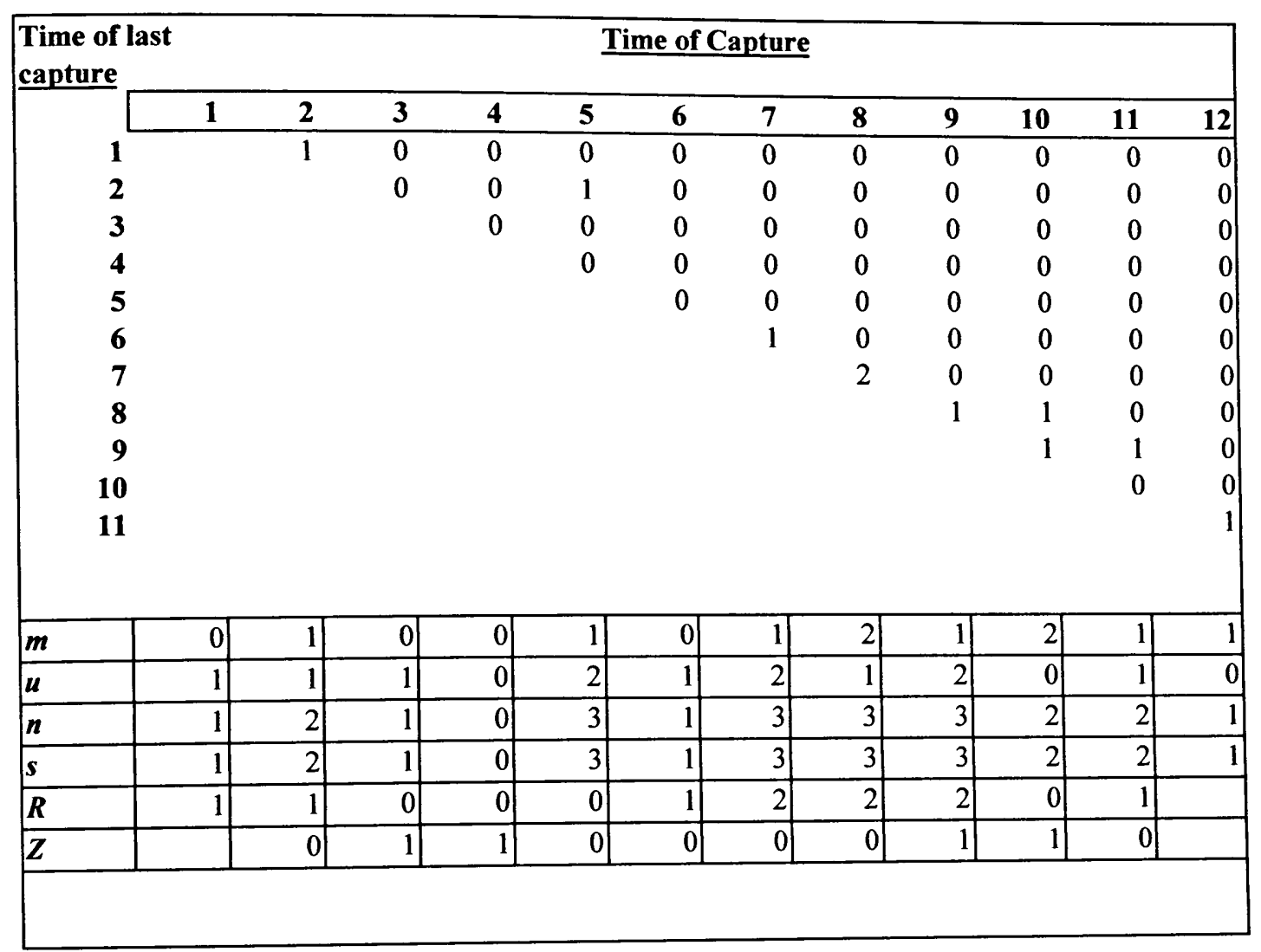

